\title{
O rei está nu: gênero e sexualidade nas práticas e decisões
}

\section{no STF}

The king is naked: gender and sexuality in the Brazilian Supreme Court practices and decisions

\section{Adriana Dias Vieira ${ }^{1}$}

1 Universidade Federal Fluminense, Niterói, Rio de Janeiro, Brasil. E-mail: a.diasvieira@gmail.com. ORCID: https://orcid.org/0000-0001-8907-7546.

\section{Roberto Efrem Filho ${ }^{2}$}

2 Universidade Federal da Paraíba, Santa Rita, Paraíba, Brasil. E-mail: robertoefremfilho@gmail.com. ORCID: https://orcid.org/0000-0001-9438-0080.

Artigo recebido em 3/05/2020 e aceito em 4/05/2020.

\section{$(\mathrm{cc})$ EY}

This work is licensed under a Creative Commons Attribution 4.0 International License. 


\section{Resumo}

Neste texto, procuramos tematizar diferentes formas como gênero e sexualidade informam práticas e decisões no âmbito do Supremo Tribunal Federal, ao tempo que políticas de gênero e sexualidade são operadas por seus ministros. Para tanto, valemonos da análise dos votos dos ministros em nove casos implicados em controvérsias públicas de gênero e sexualidade. Com isso, objetivamos investigar: a) as práticas generificadas de estruturação dos acórdãos produzidos no STF; e b) como seus ministros se empenham em uma gramática de sofrimento e na articulação da figura da vítima para reconhecer ou negar direitos.

Palavras-chave: Gênero; Sexualidade; Supremo Tribunal Federal.

\section{Abstract}

This paper aims to address different ways in which gender and sexuality shape practices and decisions in the Brazilian Supreme Federal Court, considering that the judges of the court set and define gender and sexuality related policies. Therefore, we analyze nine cases involving gender and sexuality public controversies. We aim to explore: a) the gendered practices of structuring the text of the Court's rulings; and b) whether the judges commit to build a "grammar of suffering" and how they articulate the role of the victim to recognize or deny rights.

Keywords: Sexuality; Gender; Brazilian Supreme Federal Court. 
No Brasil, a trajetória de reconhecimento dos direitos sexuais e reprodutivos e dos direitos relativos à equidade de gênero e à diversidade sexual e de gênero tem passado decisivamente pelo Supremo Tribunal Federal. Diante de uma maioria parlamentar conservadora e indisposta a parte significativa de suas pautas no Congresso Nacional, organizações da sociedade civil e movimentos sociais como os feministas e LGBTI vêm mobilizando-se em torno da corte, não raramente articulados a agentes e setores de Estado. Com isso, tais organizações e movimentos oportunizam o ajuizamento de ações e a interposição de recursos acerca daqueles direitos e acabam implicando os ministros do STF em controvérsias públicas intimamente relacionadas a políticas de gênero e sexualidade.

Tomando parte fundamental nessas controvérsias, os ministros do Supremo já decidiram sobre uma série de questões polêmicas ou moralmente sensíveis, como as uniões estáveis entre pessoas do mesmo sexo, em razão da ADI 4277 e da ADPF 132, julgadas em maio de 2011; a constitucionalidade de dispositivos da Lei Maria da Penha, através da ADC 19, julgada em fevereiro de 2012; a dispensa de representação da vítima em casos de lesões corporais de natureza leve, em situação de violência doméstica e familiar contra a mulher, com a ADI 4424, julgada na mesma data, em fevereiro 2012; a "antecipação terapêutica do parto" - ou o aborto - de fetos anencéfalos, com a ADPF 54, julgada pelos ministros em abril de 2012; a criminalização de "pederastia ou outro ato de libidinagem" presente no Código Penal Militar, por meio da ADPF 291, julgada pelos ministros em outubro de 2015; a substituição de prisão preventiva por prisão domiciliar nos casos de mulheres presas gestantes ou mães de crianças de até 12 anos ou de pessoas com deficiência, no HC 143641, julgado em fevereiro de 2018; a alteração de registro civil de travestis e transexuais, com a ADI 4275, julgada em março de 2018; e mais recentemente, em junho de 2019, a criminalização da homofobia, por conta da ADO 26 e do MI 4733.

Mesmo quando não provocados por movimentos sociais, contudo, os ministros do Supremo têm enfrentado casos que mantêm convenções morais de gênero e de sexualidade em seu cerne e que direta ou indiretamente concernem a direitos sexuais e reprodutivos ou relativos à equidade de gênero. Foi o que se deu com a ação constitucional sobre pesquisas com células-tronco embrionárias, a ADI 3510, movida em 2005 pelo então Procurador-Geral da República contra o artigo 5o da Lei de Biossegurança, com o objetivo de impedir o desenvolvimento dessas pesquisas. Mas 
também foi o que ocorreu, alguns anos antes, em 2002, com o icônico caso de Glória Trevi, no qual os ministros do STF decidiram, a propósito da Reclamação 2040, sobre a possibilidade de imposição de exame de DNA na placenta da cantora mexicana, ainda que contra a sua vontade, com o intuito de confirmar se sua gravidez havia resultado ou não de um estupro que teria sido cometido por policiais nas dependências da Polícia Federal, em Brasília, onde Trevi se encontrava presa em meio a um processo de extradição.

É possível dizer, contudo, que esses casos estão longe de encerrar o horizonte de possibilidades de incidência dos ministros do Supremo Tribunal Federal em controvérsias públicas atinentes a gênero e sexualidade. Hoje, em abril de 2020, restam em aberto na corte casos emblemáticos para o Movimento LGBTI brasileiro, como a ADI 5543, sobre a doação de sangue por homossexuais; e o RE 845779, sobre o uso de banheiros por pessoas trans de acordo com sua identidade de gênero. Também espera a decisão dos ministros a ação sobre a inconstitucionalidade da criminalização do aborto, a ADPF 442, e as ações referentes à descriminalização do aborto provocado por mulheres infectadas pelo vírus da Zika e aos direitos previdenciários e de assistência social de crianças com microcefalia e de suas mães, a ADI 5581 associada a uma ADPF. Essas três ações constitucionais sobre aborto resultaram da litigância estratégica desempenhada por militantes e organizações feministas brasileiras ${ }^{1}$ e as duas últimas, acerca do Zika, tiveram seus julgamentos iniciados em 24 de abril de 2020, no plenário virtual do STF, enquanto concluíamos este artigo².

Além disso, o recrudescimento do conservadorismo no país e sua agenda com "foco na moral sexual", como designaram Regina Facchini e Horacio Sívori (2017), têm engendrado novas controvérsias que desaguam no Supremo, como aquelas acerca da "Escola sem partido" e, sobretudo, das chamadas "leis da mordaça”, as legislações municipais que proíbem a tematização de gênero e sexualidade nas escolas e que se tornaram objeto, por exemplo, das ADPFs 460, 462, 465, 466 e 467, igualmente movidas pela Procuradoria-Geral da República. Uma dessas ADPFs, a

\footnotetext{
${ }^{1}$ Neste mesmo dossiê publicado na Direito \& Práxis, interessante artigo de Alba Ruibal (2020) analisa a trajetória da controvérsia constitucional do aborto no STF, enfatizando a relevância da ANIS - Instituto de Bioética, Direitos Humanos e Gênero para a mobilização social e o desenvolvimento de litigância estratégica em torno do tribunal.

${ }^{2}$ A ministra Cármen Lúcia, relatora da ADI 5581 e da ADPF correlata, proferiu voto, ainda em 24 de abril, julgando prejudicada a ADI e não conhecendo a ADPF. Isto significa que uma razão formal impediu a decisão sobre o mérito das ações - a constitucionalidade ou não da interrupção da gravidez quando houver diagnóstico de infeç̧ão pelo vírus da Zika, por exemplo. Como o plenário virtual não disponibiliza os textos dos votos e não há acórdão publicado, porque o julgamento permanece em andamento, nós não tivemos acesso à fundamentação do voto da ministra. Se, entretanto, Cármen Lúcia seguiu o parecer da ProcuradoriaGeral da República, este sim disponível on-line, ela pode haver julgado prejudicada a ADI 5581 por não reconhecer legitimidade à Associação Nacional de Defensores Públicos (ANADEP) para a propositura da ação. Em 27 de abril de 2020, seis outros ministros já acompanhavam o voto da relatora.
} 
457, também foi julgada pelo plenário virtual da corte no último dia 24 de abril. Em decisão unânime acerca de uma lei de Novo Gama (GO), os ministros reconheceram a inconstitucionalidade de legislação municipal que proíbe a utilização de material didático com conteúdo relacionado à diversidade sexual e de gênero ${ }^{3}$.

Partindo da compreensão da relevância de tais processos decisórios acerca de controvérsias públicas de gênero e sexualidade para os conflitos a respeito das fronteiras democráticas, nós procuramos tematizar, no presente artigo, diferentes formas como gênero e sexualidade informam práticas e decisões no âmbito do Supremo Tribunal Federal, ao tempo que seus ministros operam políticas de gênero e sexualidade. Para tanto, valemo-nos da análise dos votos dos ministros do STF em nove casos judiciais já concluídos, com acórdãos ou julgamentos publicados, e pertinentes àquelas controvérsias públicas ${ }^{4}$. As leituras dos acórdãos contaram com a aplicação de um instrumento de análise estruturado para coletar trechos das narrativas judiciais que apresentam: a) os fundamentos jurídicos dos votos de cada ministro em cada caso; b) referências à justificação exercida por cada ministro acerca da possibilidade ou do dever de decidir sobre cada caso; e c) referências às noções de "minoria", "vulnerabilidade", "sofrimento" e "vitimização", empregadas pelos ministros em seus votos, mas aqui tomadas como categorias de análise ${ }^{5}$.

Este artigo se subdivide em duas partes. Na primeira delas, nós investigamos as práticas generificadas de estruturação dos acórdãos produzidos no Supremo Tribunal Federal e, assim, os

\footnotetext{
${ }^{3}$ Porque a decisão ocorreu no plenário virtual do STF e o seu acórdão ainda não foi publicado, também não pudemos acessar os textos e fundamentações dos votos dos ministros junto à ADPF 457. Dispomos apenas de informações presentes no site do STF e na imprensa. Segundo essas informações, o plenário acompanhou unanimemente o voto do relator Alexandre de Moraes, por considerar que compete à União a edição de normas sobre currículo, conteúdo programático, exercício da atividade docente e metodologia de ensino. Conferir: http://www.stf.jus.br/portal/cms/verNoticiaDetalhe.asp?idConteudo=442331. Para acesso a análises sobre as controvérsias públicas engendradas em torno das acusações de "ideologia de gênero" nas escolas e legislações, sugerimos a leitura de: Corrêa, 2018; Leite, 2019; Machado, 2018; Carrara, França e Simões, 2018; e Machado, 2019.

${ }^{4}$ Tratam-se dos já mencionados casos das pesquisas com células-tronco embrionárias (ADI 3510); das uniões estáveis entre pessoas do mesmo sexo (ADI 4277 e da ADPF 132); do aborto de fetos anencéfalos (ADPF 54); da Lei Maria da Penha (ADC 19); da dispensa de representação da vítima em casos de lesões corporais leves quando da aplicação da Lei Maria da Penha (ADI 4424); da alteração de registro civil de travestis e transexuais (ADI 4275); da substituição de prisão preventiva por prisão domiciliar nos casos de mulheres presas gestantes ou mães de crianças de até 12 anos ou de pessoas com deficiência (HC 143641); da criminalização da homofobia e da transfobia (ADO 26 e do MI 442); e, enfim, da imposição de exame de DNA na placenta de Glória Trevi (RCL 2040-1).

${ }^{5}$ A aplicação do referido instrumento de análise foi realizada pelas autoras do texto e por um grupo de estudantes ligados(as) ao projeto de pesquisa "Mal secreto: decisões do STF e políticas de gênero e sexualidade" (PIH10556-2019), coordenado por Roberto Efrem Filho junto à Universidade Federal da Paraíba e financiado, com bolsas de iniciação científica, pelo CNPQ e pela UFPB. Os/as estudantes em questão, a quem agradecemos enormemente pela colaboração, são José Clayton Murilo Cavalcanti Gomes, Maria Mannuella de Melo Almeida, João Júnior Maciel de Oliveira, Octávio Gabriel de Barros Barbosa e Gisele Monteiro Pereira.
} 
modos como essas decisões judiciais parecem prescindir de um esforço de justificação que suplante a pressuposta autoridade do conjunto das vontades individuais dos ministros. Com isso, tanto sublinhamos a relevância dos acórdãos para a performatização da existência de uma "fala" institucional da corte - "o STF fala ou decide" sobre algo - quanto discutimos sobre como as maneiras com que "o STF decide" são tramadas em relações de gênero e de sexualidade. Por sua vez, na segunda parte do texto, nós procuramos analisar como, em seus processos decisórios, os ministros do STF se empenham em uma gramática de sofrimento e na articulação da figura da vítima para reconhecer ou negar direitos e sujeitos de direitos. Para tanto, detemo-nos nas disputas narrativas em torno de duas categorias que nos parecem ensejar ações e decisões dos ministros, as minorias e os vulneráveis. Com esses debates em mente, nós dedicamos o final do texto a algumas páginas de discussão em torno da tensa relação entre o STF, seus ministros, suas práticas e a democracia.

As duas partes deste artigo se desenlaçam através de referências a duas fábulas, que nos servem ora como metáfora, ora como chave poética, ora como recurso metodológico por meio dos quais nós nos defrontamos com o nosso objeto de análise, as práticas e decisões do STF. A primeira fábula dá título a este texto - "O rei está nu" - e é mencionada na canção "Estrangeiro", de Caetano Veloso. A fábula, contudo, tornou-se conhecida sobretudo através do conto infantil "A roupa nova do imperador", do dinamarquês Hans Christian Andersen, inspirado numa história encontrada em uma coletânea medieval espanhola chamada "Libro de los ejemplos"6. No conto de Andersen, um rei vaidoso aceita pagar bastante caro a um pretenso alfaiate - um bandido fugido de outro reino - por uma roupa que somente os inteligentes conseguiriam ver. $\mathrm{O}$ rei, mesmo sem ver a roupa, decide inaugurá-la e exibi-la publicamente, contando com a admiração e os elogios constrangidos de seus ministros e súditos, isto até que uma criança em meio à multidão acaba gritando "o rei está nu". Nas próximas páginas, a nudeza do rei será dimensionada principalmente através dos versos da música de Veloso ${ }^{7}$. Enfim, a segunda fábula com que lidamos neste artigo remete ao conceito empregado pela antropóloga

\footnotetext{
${ }^{6} \mathrm{O}$ "Livro de los ejemplos" reúne cinquenta e cinco contos, de diferentes fontes, compilados por Juan Manuel, Príncipe de Villena. Segundo Annette Madsen (1999), a versão da história adotada por Andersen difere em alguns pontos daquela do livro de Juan Manuel. No que seria o conto original, um rei recebe de tecelões uma roupa visível apenas aos filhos legítimos. Assim, o conto medieval provocava uma discussão sobre a autenticidade do filho e, portanto, a legitimidade do rei.

7 A canção "Estrangeiro" pertence ao álbum "O Estrangeiro", lançado por Caetano Veloso, através da gravadora Elektra Musician, em 12 de novembro de 1989. Para uma análise da canção no campo da antropologia, ver: Rocha, 2001.
} 
Mariza Corrêa (1983) que, em estreito diálogo com Propp (1928), cunhou uma metodologia de estudo de autos judiciais que viria a se tornar imprescindível aos estudos de gênero e sexualidade e aos estudos sobre violência no país.

Antes de seguir, porém, importa notar que nossa escolha por percorrer analiticamente as práticas dos ministros - nas quais se incluem suas tomadas de posição, seus esforços decisórios, assim como as formas com que exercem tais esforços - resulta do profícuo contato que estamos estabelecendo com análises situadas na interseção entre a antropologia do Estado e os estudos de gênero e sexualidade. Em estreito diálogo com as contribuições de Philip Abrams (1988) e Timothy Micthell (1999), tais análises têm voltado atenção para as práticas e os agentes que participam do trabalho contínuo, cotidiano e burocrático de produção do Estado. Assim, elas se têm desenvolvido a partir de pesquisas, de regra etnográficas, em torno da prisão e do encarceramento (Lago, 2020; Padovani, 2017), de lutas por justiça em contextos de violência e criminalização (Vianna e Farias, 2011; Lacerda, 2014; Efrem Filho, 2017a, 2017b) e no interior de órgãos de Estado, como cartórios policiais, repartições judiciais, núcleos de defensoria pública, conselhos de participação social e instâncias de formulação e de execução de políticas públicas (Ferreira, 2013; Lowenkron, 2012; Nadai, 2012; Lugones, 2017; Veiga, 2018; Aguião, 2014; Freire, 2015; Paschoal, 2020; Feitosa, 2019). Contudo, essas mesmas análises também se vêm dedicando a perscrutar documentos, suas técnicas de formatação e estruturação e as relações de poder que os atravessam, reconhecendo que suas páginas, segundo notou Letícia Ferreira (2013), funcionam como espaços de tomada de posição e, mais do que registrar o que existe previamente, participam da configuração e do rearranjo daquelas relações de poder, incitando a produção de sujeitos de direitos e inclusive do que se chama de Estado.

"Estado", portanto, seguindo as análises de que estamos tratando, não consiste em um "ente" ou sujeito a conjugar verbos por si mesmo. "Estado" consiste em seu próprio fazer, de que é parte inclusive o exercício de sua invocação como ente ou sujeito, tal qual é parte o esforço de construção de sua separação em relação àquilo que é tido, do outro lado, como sendo "a sociedade", "a economia", "a religião" ou "a sexualidade". Sendo assim, faz-se Estado nas práticas e em seus agenciamentos, até mesmo no conflitivo processo de constituição de suas fronteiras. Práticas de Estado se realizam em decisões judiciais, na reunião solene de onze ministros cobertos com togas negras no plenário do Supremo Tribunal Federal, nos modos como eles recorrem a artigos da 
Constituição Federal ou à jurisprudência da corte para justificar suas posições e ratificar sua autoridade, como arquitetam seus acórdãos e impõem o brasão do tribunal nas folhas que assinam. Práticas de Estado concernem, enfim, aos conflitos a respeito da fixação da imagem de um Supremo que decide e, com isso, reconhece ou não direitos, conforma ou não sujeitos de direitos.

Adriana Vianna e Laura Lowenkron (2017) têm notado, no entanto, que se "Estado" está nas práticas e nos agenciamentos que produzem Estado, esta produção se dá em correlação à produção de gênero. É assim que Vianna e Lowenkron (2017) falam em um "duplo fazer do gênero e do Estado", noção esta fundamental para as análises que neste texto experimentamos, a qual tanto supõe que gênero e Estado se coproduzem quanto requer, analiticamente, uma percepção desestabilizadora de ambas as categorias, de maneira que nem gênero nem Estado sejam pressupostos ou predefinidos, mas considerados como abertos a experiências e conflitos, àquilo que as autoras chamam de "relacionalidade profunda entre os jogos de generização do Estado e estatização do gênero". Disso decorre a sua conclusão de que Estado não é essencialmente masculino, como certos feminismos haviam antes consignado (Mackinnon, 1989). Isto porque:

Ao invés de definirmos a priori um gênero fixo que caracterizaria o Estado, portanto, consideramos que ambos, gênero e Estado, se fazem em ato, devendo ser entendidos e apreendidos a partir de (e como) seus efeitos performativos, performances e materialidades contextualmente situados (Vianna e Lowenkron, 2017).

Sendo assim, é tendo essa interpretação de Adriana Vianna e Laura Lowenkron (2017) em vista que nós procuramos discutir, nas próximas páginas, como relações de gênero e de sexualidade informam práticas e decisões dos ministros do Supremo Tribunal Federal. Para o desenvolvimento dessa discussão, volvemo-nos aos documentos, aos acórdãos e suas narrativas judiciais, os quais materializam práticas e decisões desempenhadas pelos ministros "em atos" a respeito de controvérsias públicas relativas a gênero e sexualidade e a partir dos quais se vêm configurando como uma instância de conflitos políticos e de reconhecimento ou sonegação de direitos cada vez mais proeminente e crítica para a nossa experiência democrática. 
1. 0 rei é mais bonito nu: sobre práticas generificadas de estruturação dos acórdãos no STF

Na canção Estrangeiro de 1989, Caetano Veloso retoma a fábula que dá título a este artigo e, subvertendo a moral a esta historicamente associada, enuncia que "é um desmascaro / singelo grito: / 'o rei está nu' / mas eu desperto porque tudo cala frente ao fato de que o rei é mais bonito nu". Na canção, é o eu-lírico da canção, o compositor - o mesmo que afirma que suas canções são todas autobiográficas, até as que não são, são (Veloso, 2003, p. 37) - que dá o singelo grito, diante da conversa tenebrosa $a^{8}$ que se anuncia entre o "velho com cabelo nas narinas" e a "menina ainda adolescente e muito linda". O "terno negro do velho" e os "dentes quase tão púrpura da menina", somados ao lugar em que a conversa se deu, a "praia de botafogo era uma esteira rolante de areia / branca e óleo diesel", área nobre da zona sul carioca, sugerem suavemente na canção os marcadores de classe, raça e território de todos os atores envolvidos, tanto dos que falam quanto do próprio Caetano.

Como observou Acauam Oliveira (2015), a obra de Caetano é um ponto privilegiado de observação do projeto estético de modernização - que culmina, no campo estético, com a consolidação da "MPB" e; do ponto de vista político, com um certo projeto do Brasil como Estado-nação [mestiço, cordial, da democracia racial] - e, portanto, das potencialidades e limites deste projeto. Analisando a canção "Haiti" ${ }^{9}$, Oliveira (2015) aponta que existe uma "diferença decisiva em relação ao rap, que historicamente constrói seu ponto de vista a partir de baixo, mesmo quando se dirige para/contra quem está acima (...) Caetano e Gil, ao contrário, reconhecem já de saída que participam, junto a seu interlocutor, das comemorações oficiais" (Oliveira, 2015, p. 141).

O interlocutor para a qual a canção se dirige é um "você" que foi convidado para assistir, de cima, o espetáculo de violência e encanto que se desenvolve embaixo. A canção, por sua vez, assume um ponto de vista ao lado de seu

\footnotetext{
$8 \mathrm{Na}$ canção, o velho e menina conversam e ele, Caetano, "ouve as vozes / os dois me dizem / num duplo som / como que sampleados num Sinclavier: / "É chegada a hora da reeducação de alguém / do Pai do Filho do Espírito Santo amém / o certo é louco tomar eletrochoque / o certo é saber que o certo é certo / o macho adulto branco sempre no comando / e o resto ao resto, o sexo é o corte, o sexo / Reconhecer o valor necessário do ato hipócrita / riscar os índios, nada esperar dos pretos".

${ }^{9}$ Os versos que abrem a canção "Haiti", de Caetano e Gil, são: "quando você for convidado / pra subir / no adro / da fundação/ Casa de Jorge Amado / pra ver do alto a fila de soldados pretos / dando porrada / na nuca de malandros pretos / de ladrões mulatos e outros quase brancos / Tratados como pretos / Só pra mostrar aos outros quase pretos (E são quase todos pretos) / E aos quase brancos pobres como pretos / Como é que pretos, pobres e mulatos / E quase brancos quase pretos de tão pobres são tratados".
} 
interlocutor, de onde também contemplará o espetáculo grotesco (Oliveira, 2015, p. 141).

Em Estrangeiro, também existe um "você" a quem a canção se dirige indiretamente, e o interlocutor é também convidado a contemplar um outro "espetáculo grotesco": não a violência policial do mundo "lá de baixo", mas do que se escuta "em cima", seja no adro da Fundação Casa de Jorge Amado ou na praia de Botafogo.

A questão das relações de poder, portanto, concerne a produções de todos os sujeitos [os que denunciam e os que são denunciados] e suas estratégias, seus lugares de fala e suas posições. Cortes constitucionais são, neste sentido, necessariamente, lugares de exercício do poder e cada vez mais proeminentes no discurso político (Slaughter, 1995 e 2004; Bellamy e Castiglione, 1997; Vojvodic, Machado e Cardoso, 2009; Vieira, 2008; Arguelhes e Ribeiro, 2018; Vieira, 2014). Os ministros do STF são, portanto, resultado de muitos filtros [políticos, culturais, de raça, gênero, sexualidade, classe, origem etc.], enquanto pessoas "convidadas" - literalmente - a "subir no adro" do Poder Judiciário. As suas falas transpiram esta posição de privilégio em que masculinidades e feminilidades específicas são tensionadas, numa trama complexa de falas, sotaques e silêncios. No julgamento da constitucionalidade de dispositivos da Lei Maria da Penha, ADC 19, o Ministro Ayres Britto enunciou o seguinte:

\footnotetext{
A nossa cultura é patriarcal, a Ministra Cármen Lúcia enfaticamente disse isso, e com autoridade de quem sente na pele, na alma, os efeitos danosos, perniciosos de uma cultura machista ou patriarcal que tanto desfavorece $o$ gênero feminino. E é caminhar também - eu acho que vai dizer isso no seu certamente luminoso voto o Ministro Celso de Mello - no sentido da afirmação do processo civilizatório. Daí por que tantos tratados internacionais. Eu tenho aqui meia dúzia deles; não vou fazer a citação. Esses tratados exigem dos Estados-partes uma legislação confirmadora da proteção específica da mulher contra a violência: violência sexual, violência psicológica, violência física. E eu que, de vez em quando, massageio o meu próprio ego, faço um autoelogio, dizendo que tenho facilidade para citar autores que cunham frases consagradoras de verdadeiras lições de vida, hoje, não me vem à memória o nome desse autor que disse magnificamente o seguinte: 'O grau de civilização de um povo mede-se pelo grau de proteção da mulher" (Ayres Britto, ADC 19, p. 55) ${ }^{10}$.
}

\footnotetext{
${ }^{10}$ Neste artigo, as citações aos votos dos ministros indicarão as páginas de onde os trechos foram retirados de acordo com a numeração existente no arquivo de PDF do "inteiro teor do acórdão" gerado no site do Supremo Tribunal Federal. A maior parte desses acórdãos é numerada da página 01 em diante. Em alguns poucos casos, a numeração das páginas do acórdão continua a contagem das páginas de documentos anteriores à decisão final dos ministros, presentes nos autos da ação judicial como um todo. Encontramos, porém, um problema quanto à citação dos votos dos ministros do STF junto à ADO 26 e ao MI 4733, visto que o site do STF não disponibiliza o arquivo do inteiro teor. Assim, encontramos alguns votos no site de notícias do tribunal e os demais nós precisamos analisar a partir de vídeos disponíveis na plataforma Youtube.
} 
É dentro desta chave de produção de sujeitos e relações de poder que podemos ler a fala do ministro que denuncia a cultura patriarcal para, na mesma frase, afirmar que "o grau de civilização de um povo mede-se pelo grau de proteção da mulher". Voltando ao discurso cancional de Estrangeiro, observamos uma transvaloração muito particular e irônica da nudez em algo "bom", no sentido do que ela, a nudez, escancara em termos de possibilitar ver, sentir e escutar, a violência mais crua de quem defende a manutenção de um projeto nacional que garanta "o macho adulto branco sempre no comando", reafirme "o valor necessário do ato hipócrita", projeto este explicitamente genocida e racista quando fala em "riscar os índios, nada esperar dos pretos". A violência é, portanto, uma chave central para entender os dispositivos dos quais os ministros se valem em suas práticas performáticas e, enquanto zona de significação, como definiu Vianna (2014), esta, a violência, é sempre generificada nos jogos de linguagem e funciona como "vetor importante de generificação do Estado, distribuído entre representações, atos e práticas centrados na importância de conquistar, submeter e combater, mas também de proteger, restaurar e conduzir" (Vianna e Lowenkron, 2017).

Entendemos, neste artigo, estas duas provocações - da fábula e da canção como chaves poéticas para pensar o nosso problema de pesquisa, qual seja, entender como o STF "faz" política de gênero e de sexualidade, ao mesmo tempo que ele próprio "é" e "faz" Estado - seja ao se afirmar, se reinventar, se reificar, se folclorizar, se negar, se mediatizar etc. - uma estrutura de Estado atravessada por relações e conflitos de classe, raça, gênero, sexualidade etc., impossíveis de serem, na experiência concreta, dissociados (Scott, 1995; Vianna e Lowenkron, 2017). As aspas, que abundam neste texto, são agnósticas, na linha de Castro (2007), e convidam a um distanciamento necessário, na nossa pesquisa, do campo. O distanciamento, e mais, o estranhamento, é tanto mais difícil quanto mais familiar nos é o objeto, porque, como ensina Gilberto Velho, "o que sempre vemos e encontramos pode ser familiar mas não é necessariamente conhecido e o que não vemos e encontramos pode ser exótico mas, até certo ponto, conhecido" (Velho, 1978, p. 73).

O STF não é um ente dotado de uma vontade, por mais que o ensino hegemônico do direito - ou seja, o grosso da produção da dita dogmática jurídica e mesmo dos estudos acadêmicos no campo do direito -, por razões que extrapolam os objetivos deste artigo, busquem sustentar. A construção material e simbólica desta "unidade" - que "acolhe", "fundamenta" e "decide" -, é tramada por um complexo de 
práticas discursivas e burocráticas que buscam "monolitizar" o Estado através de apagamentos, silenciamentos e performances [de gênero, sexualidade, raça, classe, origem etc.] com vistas à personificação do Estado [O Estado "pensa", "fala", "decide"] que está encravada no coração das teorias jurídicas liberais: "a corte", e sobretudo "a corte constitucional" precisa dar "a última palavra" e ser "a guardiã da Constituição".

No campo judicial, a teoria jurídica liberal resolveu a questão da unidade discursiva sugerindo, a partir do modelo da common law (Coke, 1642; Blackstone, 1765, Dicey, 1982), votações majoritárias sobre a justificativa para a decisão [a chamada razão de decidir ou ratio decidendi, na dita linguagem técnica ou especializada] e da decisão propriamente de mérito [ou parte dispositiva da sentença], permitindo, em maior ou menor grau, a publicização do dissenso. O resultado final desta operação é que o acórdão, documento que formaliza a decisão judicial de tribunais colegiados, firma a posição "da corte" e, a depender do modelo de jurisdição, pode-se ter acesso aos nomes dos ministros que dissentiram e, eventualmente, as suas razões.

Ao contrário de outras cortes constitucionais ou supremas cortes, o STF se deixa ver a claro, tanto no sentido literal, tratando-se da única corte constitucional do mundo a televisionar ${ }^{11}$, na íntegra, suas decisões em sede de plenário numa TV pública do Poder Judiciário, a TV Justiça, quanto também na forma como decide e procedimentaliza seus julgamentos e a formalização de suas decisões, os acórdãos.

Os acórdãos, enquanto materializações administrativas, adequam, encarnam e fetichizam relações, expressões e práticas de gênero e inscrevem nos "corpos, relações e imaginações" o que é o "bom" Estado, bem como "configuram continuamente os contornos e possibilidades de Estado e gênero, mas sobretudo as diferenças, desigualdades e violentas hierarquias que distinguem o "bom" gênero de seus outros" (Vianna e Lowenkron, 2017). Neste sentido, como observou Vieira (2014), os acórdãos materializam, em termos wittgensteinianos, os modos de vida que serão legitimados, negociando continuamente com a sociedade os termos do debate sobre o uso 'legítimo' da força.

Trata-se, por estas razões, historicamente, de um documento importante que formaliza as decisões dos órgãos judicantes colegiados. Na Inglaterra, por exemplo, é um

\footnotetext{
${ }^{11}$ Sobre as consequências do televisionamento das decisões do STF, ver Arguelhes e Ribeiro, 2018.
} 
conjunto de julgados [acórdãos, portanto] da House of Lords que constitui a Constituição inglesa clássica, único exemplo de constituição moderna 'formalmente' não escrita.

É, portanto, um dado muito relevante os modos pelos quais o STF "fala", ou seja, os modos pelos quais o tribunal formaliza suas decisões e as publiciza, ou seja, como "faz" os seus acórdãos. A decisão sobre como 'fazer' os acórdãos, assim como tudo o mais no campo do Estado, é atravessada por dinâmicas, performances e prática de gênero e sexualidade - que dizem muito, e talvez ainda mais quando calam, sobre "o que estão dizendo / aquela cara / e aquela", para voltar, por um momento, à canção. Ou seja, a forma como o STF "decide" formalizar e publicizar o resultado de seu labor [fundamentar e decidir] diz muito sobre o tipo de autoridade que invoca.

Na práxis, o acórdão do STF é um documento confuso, normalmente longo, que carece de unidade, composto apenas da ementa de decisão, dos votos de todos ou de parte dos ministros [como veremos, não há uniformidade nem neste aspecto, nem explicação ou justificativa para tal], das transcrições dos debates que aconteceram durante o julgamento e do extrato das atas. A unidade é forjada, em nível muito superficial e sem maiores preocupações, por um cabeçalho que enumera todo o documento e enuncia tratar-se do "inteiro teor do acórdão".

A ficção, portanto, nunca se opera. O STF nunca "fala", mas apenas falam os seus ministros. Ademais, os acórdãos "podem", sem maiores justificativas técnicas, "não disponibilizar" o voto de um Ministro que, entretanto, "consta" na ementa como tendo participado e votado na decisão. Não terá o Ministro entregue o voto por escrito? São informações aparentemente simples e que, entretanto, ficam sem resposta. No acórdão da ADI 4424, por exemplo, há expressa supressão das falas do Ministro Celso de Mello nas transcrições dos debates com uma advertência de "cancelado" e, entretanto, consta o seu respectivo voto escrito e sua participação na votação.

No caso da ADO 26 e do MI 4733, o assunto é mais complicado. Apesar de o julgamento destas ações ter sido encerrado em junho de 2019, ainda não foi publicado o acórdão da decisão. $\mathrm{O}$ arquivo, como apontamos, ainda não está disponível no site do tribunal, em desrespeito à Resolução 537 do próprio Tribunal que regulamenta a publicação de acórdãos no STF, prevista no artigo 95 do Regimento Interno da Corte, e fixa o prazo de 60 dias após a realização da sessão de julgamento para que esses documentos sejam publicados. Já na RCL 2040, conhecida como caso Gloria Trevi, não temos acesso aos votos dos ministros Celso de Mello, Ellen Gracie e Nelson Jobim, tendo 
todos eles seus votos computados, nos termos das respectivas ementas, e não há justificativa para tal. No caso da ADPF 54, por sua vez, não temos o voto da ministra Ellen Gracie, também sem justificativa ou anotação que explique a dinâmica do tribunal.

Observadas estas características e particularidades das práticas e decisões no STF, parece-nos importante examinar e problematizar o tipo de reflexão que tem sido construída sobre os modos pelos quais os acórdãos são produzidos no tribunal. Existe, na verdade, um campo de estudos consolidado em torno da argumentação jurídica e da jurisdição constitucional, sobretudo no mundo anglo-saxão, e constitui um índice epistemológico de questões. O modelo da common law nasce na Inglaterra a partir da primeira revolução burguesa, que antecipa em quase cem anos as demais revoluções burguesas no continente europeu, e inaugura um modelo particular e excepcional de modelo jurídico, o "rule of law" inglês. Muito mais baseado em jurisprudência do que em leis - a Constituição inglesa é a única experiência ocidental de Constituição não escrita formalmente, a common law é caracterizada como a verdadeira fonte da liberdade (Coke, 1642; Blackstone, 1765, Dicey, 1982). A jurisprudência é, portanto, a maior fonte de direitos e segurança jurídica. É na common law que se consolida a noção de precedente vinculante, e a atitude de seguir a ratio decidendi de precedentes é intrinsecamente ligada ao que chamaremos de cosmogonia jurídica inglesa que coloca a jurisprudência como o lugar de descoberta e declaração daquilo que o direito é: antigo costume espontâneo $a b$ immemorabilia. A cultura jurídica anglo-saxã é voltada para o estudo de precedentes judiciais. Esta ênfase no Poder Judiciário, bem como a ausência de leis gerais abstratas que pudessem servir de fundamentação para as decisões judiciais, forçou o judiciário inglês, desde o final do séc. XVII, a argumentar. Como observou Strauss (1996), as cortes da common law têm um método argumentativo típico, baseado numa gramática jurídica de elementos não positivados, não formais, mas persuasivos e extra-sistêmicos. Este modelo, por via do soft power desenvolvido pelo Privy Council (Ciufolletti, 2011) e pela força bruta do império britânico, foi levado às colônias inglesas, marcando um modelo de commonwealth que, por relações e dinâmicas complexas de poder global, é hoje muito relevante no mundo. As teorias argumentativas, portanto, são índices epistemológicos de uma determinada forma de pensar o direito e o papel dos juízes, tendo repercussão direta no tipo de saber que deve ser estudado, pesquisado e ensinado.

O Brasil, para estes pesquisadores, "demorou" a começar a "olhar" para sua jurisprudência e analisar as decisões judiciais. Como os estudos pioneiros de Vojvodic, 
Cardoso e Machado (2009) sobre o STF apontaram, inexiste a cultura dos precedentes judiciais no STF. Os precedentes judiciais, típicos dos sistemas jurídicos da common law, exigem clareza e publicidade da razão de decidir ["ratio decidendi"] "da corte".

Os ministros estão diante de casos difíceis, em que há necessidade de decidir formando um precedente que sirva de parâmetro para a decisão de futuros casos. A argumentação é alvo de maior atenção, seja por parte dos próprios ministros, seja por parte da sociedade. Ainda assim, alguns aspectos importantes relacionados à coerência da decisão não são observados. Por exemplo, o que é ratio decidendi (linha argumentativa principal, que pode ser utilizada como precedente em casos futuros) e o que é obter dictum (opinião dos ministros expressa nos votos, a qual não produz efeitos na solução de casos futuros)? A ratio decidendi é do ministro ou do Tribunal? Em que medida o atual processo decisório do STF oferece entraves à legitimidade das decisões do Tribunal nesse novo contexto? (Vojvodic, Cardoso e Machado, 2009, p. 26).

Como observaram Arguelhes e Ribeiro (2018), na última década se consolidou, na literatura, um importante conjunto de trabalhos dedicados à análise dos processos decisórios no Supremo Tribunal Federal, de regra relacionando-os ao debate mais amplo sobre a legitimidade de uma corte constitucional num regime democrático. Para Rodriguez, "a corte decide por agregação de opiniões sem elaborar uma fundamentação unificada de sua argumentação" (Rodriguez, 2013, p. 83). E como é usual que todos os ministros se pronunciem e construam sua própria argumentação, sobretudo em casos mais complexos, o resultado é que a corte opera apenas na parte dispositiva da decisão [se condena ou não condena, se concede ou não concede, se declara inconstitucional ou não etc.], mas não no campo argumentativo, ou seja, da justificação ou razão de decidir. Não há votação no campo argumentativo, mas apenas na parte dispositiva. Em alguns casos, este sistema, estabelecido surdamente ${ }^{12}$ pelo STF, gera incompreensão acerca do resultado da decisão, inclusive entre os ministros. Como apontaram Vojvodic, Cardoso e Machado (2009), na votação da ADI 3510, a ação sobre as pesquisas com células-tronco, houve o seguinte impasse:

\footnotetext{
Um elemento que chama a atenção nos votos individuais desses cinco ministros que decidiram pela inconstitucionalidade das pesquisas é a inclusão de condições à interpretação de constitucionalidade da lei, o que eles denominaram "decisão aditiva", uma nova possibilidade de atuação do STF como legislador positivo. Preocupados com que a efetivação das pesquisas fosse baseada em parâmetros éticos, os ministros condicionaram sua

12 Tratando da relação entre a história da mineração e a obra de Carlos Drummond de Andrade, José Miguel Wisnik recupera, do poema "Procura da poesia", a palavra "surdamente" quando o poeta fala em penetrar "surdamente o reino das palavras". Sobre o uso do termo "surdamente" em seu texto, Wisnik aponta tratarse do "lugar sub-reptício das coisas invisíveis de tão óbvias" (Wisnik, 2018,p. 18).
} 
liberação à instituição de um órgão central de controle do uso de célulastronco, à adequação de alguns termos técnicos presentes no texto da lei, à inclusão de uma cláusula de subsidiariedade para o exercício das pesquisas, entre outras medidas. Cada ministro previu uma condição diferente, os votos não se comunicavam. Cada voto de caráter "aditivo" era computado pelo placar binário de votação como sendo pela inconstitucionalidade das pesquisas. Essa forma de contabilização gerou polêmica. O ministro Cezar Peluso discordou da contabilização de seu voto como sendo pela inconstitucionalidade da lei, pois entendeu que a essência de seu voto (sua ratio decidendi) era favorável à realização das pesquisas. No placar, a maioria pendeu pela constitucionalidade da lei, pela permissão incondicionada das pesquisas. Mas e se fosse o contrário? E se os votos que estabelecem condições díspares entre si formassem um placar majoritário? A Lei de Biossegurança seria completamente inconstitucional? (Vojvodic, Cardoso e Machado, 2009, p. 26).

O STF se mostra, tal qual o rei da fábula [e também da canção, como veremos], nu, sem nenhum tecido, argumentativo ou formal, que o vista. Tanto os vídeos dos julgamentos, quanto os acórdãos documentam um STF nu, sem "uma" fala "própria", mas, muitas vezes, com onze possibilidades de razões de decidir não votadas e, portanto, não discutidas. Ou seja, o acórdão documenta a inexistência da razão de decidir, ao mesmo tempo que agrupa as opiniões dos ministros. Tem-se claro e público o resultado da votação, ou seja, a parte dispositiva da sentença e, portanto, temos claro o encaminhamento pragmático do STF sobre uma questão. Entretanto, inexiste mecanismo institucionalizado - nem nas normativas, nem na práxis - que obrigue os juízes a votarem a chamada razão de decidir. Como apontam Vianna e Lowenkron (2017), os modos pelos quais os atores "evocam, repudiam e silenciam acerca de instâncias, representações e práticas estatais ou estatizantes muito nos diz sobre o próprio Estado - seja em sua dimensão de ideia ou sistema - como espaço de disputa ideológica, existencial e política". Em termos de gênero e sexualidade, os modos como as decisões do STF parecem prescindir de um esforço de estruturação formal dos acórdãos, bem como de justificação das decisões, são paradigmáticas da forma como a violência atravessa o cotidiano das instituições e da vida brasileira. Trata-se de uma forma particular de violência, como são o racismo brasileiro e, de resto, o Brasil.

A magnitude desta questão permite várias perspectivas de análise. Neste estudo, exploraremos a relação entre a não justificação das decisões e os "atos de fala que se inscrevem em malhas de contínua produção de sujeitos, projetos políticos, horizontes morais e elaboração de experiências" (Vianna e Lowenkron, 2017). 
Primeiro, é preciso pontuar que as dinâmicas e performances dos Ministros tecem uma ocultação/dissimulação muito particular da ausência de justificação "da corte", através de um procedimento de superexposição [seja pelo televisionamento, seja pela quantidade de páginas, seja pela confusa discricionariedade com que o tribunal "monta" sua pauta ${ }^{13}$, afeta processos, dá ou não repercussão geral, bem como pela profusão de argumentos, opiniões, enquanto elemento constitutivo do acórdão]. Como, argumentando tanto, o STF não argumenta?

Esta é uma chave importante para entender as contradições e ambivalências que permeiam as preocupações "do STF", ou seja, dos seus ministros, com a fundamentação da decisão. Conhecedores dos processos decisórios e das práticas de outras cortes constitucionais bastante influentes - ou persuasivas - no campo "da proteção dos direitos humanos" - onde estão inseridas as reivindicações "clássicas" concernentes a gênero e sexualidade [e que, portanto, se concentram sobre direitos das mulheres, LGBTI etc.] -, os ministros muitas vezes têm, em seus respectivos currículos, passagem por universidades prestigiadas localizadas no que podemos chamar de centro epistêmico do saber jurídico, e apresentam, em seus votos, conhecimento avançado não só de jurisprudência "estrangeira", mas de modos específicos de argumentar e julgar certos modelos de jurisdição bastante "importantes" no mundo. É o caso do ministro Gilmar Mendes e de sua constante referência ao modelo de jurisdição da Corte Constitucional Alemã, país em que estudou e que tem uma jurisdição (ou "legal reasoning", para usar um marcador do debate no campo argumentativo) particularmente influente no campo dos discursos sobre a dignidade humana, que fundamenta grande parte das decisões das cortes constitucionais e internacionais no campo das disputas de gênero e sexualidade (Macklin, 2002; Millns, 2004; Whitman, 2004; Dupré, 2009; Rosen, 2012; Waldron, 2012; Vieira, 2014). Também é o caso do Ministro Luís Roberto Barroso. Depois de vencer casos importantes no STF como advogado ${ }^{14}$, passou um ano como

\footnotetext{
${ }^{13}$ Sobre o assunto, ver Santos, 2017.

${ }^{14}$ Luís Roberto Barroso, antes de ser nomeado Ministro do STF, atuou como advogado em dois casos de grande repercussão social e midiática no STF concernentes a gênero e sexualidade, sendo vitorioso na ADI 3510/DF (2008), que dizia respeito à constitucionalidade da lei de biossegurança e possibilidade de pesquisa com células-tronco, em advogou em nome do Movimento em prol da vida (MOVITAE), bem como ADPF 54/DF (2012), que dizia respeito à recepção, pela Constituição Federal, de interpretação do código penal brasileiro que proibia a interrupção de gravidez em caso de fetos anencéfalos, em que ele atuou em nome do Confederação Nacional dos Trabalhadores na Saúde.
} 
visiting scholar na Universidade de Harvard e, sob clara influência dworkiniana, escreveu um artigo especialmente dedicado ao discurso transnacional sobre a dignidade humana ${ }^{15}$. É, portanto, dentro desta ambivalência, que devemos entender o voto do Ministro Gilmar Mendes, à época presidente do STF, junto à mesma ADI 3510. Trata-se de uma argumentação longa, com extensa análise das razões de decidir em caso similar na experiência alemã, australiana, espanhola e italiana, para por fim enunciar voto pela inconstitucionalidade das pesquisas, bem como fazer profecias de como o STF "seguirá" o modelo das "principais" cortes constitucionais europeias.

Portanto, é possível antever que o Supremo Tribunal Federal acabe por se livrar do vetusto dogma do legislador negativo e se alie à mais progressiva linha jurisprudencial das decisões interpretativas com eficácia aditiva, já adotadas pelas principais Cortes Constitucionais europeias (2008, p. 629).

Como os estudos pioneiros de Anne-Marie Slaughter (1995) apontaram, há crescente "diálogo" entre as cortes, sobretudo entre cortes internacionais e as cortes constitucionais estatais. As implicações e os sentidos destes "diálogos entre as cortes" têm despertado o interesse de pesquisadores (Slaughter, 1995 e 2004; Ciuffoletti, 2011; Barroso, 2012; Vieira, 2014) e merecem ulteriores estudos, sobretudo a partir de perspectivas decoloniais de gênero e raça, na medida em que podem problematizar a dependência epistêmica por parte de algumas cortes em relação à "capacidade persuasiva" de outras. Enquanto no Brasil, o STF "cita" as "principais cortes constitucionais europeias" em muitos dos seus julgados, o contrário pouco ou quase nunca acontece ${ }^{16}$. Como dissemos, o caso do Ministro Gilmar Mendes não é um caso isolado. A Ministra Rosa Weber, tanto no julgamento da ADC 19 quanto no julgamento da ADI 4424 [em que a Ministra citou o seu próprio voto na decisão da ADC 19], recorreu aos argumentos de autoridade da Corte Europeia de Direitos Humanos. Ao contrário do pedido principal que baseava o pedido da constitucionalidade da Lei Maria da Penha com base no princípio da igualdade, a Ministra buscou justificar seu voto com base no sentido

15 Ver Barroso, 2012. O texto foi publicado depois, em português, em formato de livro, sob o título "A Dignidade da Pessoa Humana no Direito Constitucional Contemporâneo - A Construção de um Conceito Jurídico à Luz da Jurisprudência Mundial". Ver Barroso, 2013.

${ }^{16}$ No campo dos discursos judiciais sobre a dignidade humana no STF, na Corte Interamericana de Direitos Humanos (IACtHR) e na Corte Europeia de Direitos Humanos (ECtHR), os estudos de Vieira (2014) apontam um único caso em que a ECtHR cita a IACtHR no campo da construção jurisprudencial do direito à verdade como direito de não ser submetido a tratamento ou pena cruel, desumano e degradante. O contrário é muito comum. Não há citação ao STF por parte da ECtHR em nenhum dos julgados, mas há citação a outras cortes constitucionais, como a corte constitucional sul-africana. O diálogo surdamente travado entre STF e IACtHR também merece aprofundamentos. 
da proteção das leis antidiscriminatórias e apontou que "na precisa definição da Corte Europeia de Direitos Humanos, 'discriminação significa tratar diferentemente, sem um objetivo e justificativa razoável, pessoas em situação relevantemente similar" (Willis vs. Reino Unido, § 48, 2002; Okpisz vs. Alemanha, § 33, 2005)'” (ADC 19, p. 23). Mais à frente, a ministra pontuou:

Esse aspecto ficou muito bem delineado no julgamento do caso Opuz vs Turquia, perante a Corte Europeia de Direitos Humanos, em 2009, que resultou na condenação do Estado demandado - a Turquia - por falhar em fornecer, na legislação doméstica, mecanismos suficientes de proteção em face da violência praticada contra a mulher no ambiente familiar. No caso, norteou a decisão o fato de que o Estado não poderia prosseguir com a ação penal contra o agressor, na hipótese de retratação da vítima, quando se tratasse, mal comparando, de lesão corporal considerada, nos moldes daquela jurisdição penal, menos grave. $O$ arcabouço legislativo então em vigor foi censurado, por esse motivo, pela Corte Europeia de Direitos Humanos, por estar "(...) aquém dos requisitos inerentes às obrigações positivas do Estado de estabelecer e aplicar efetivamente um sistema que puna todas as formas de violência doméstica e forneça salvaguardas suficientes para as vítimas", assentando-se, ainda que "as autoridades responsáveis pela persecução deveriam ter sido capazes de prosseguir com o processo como questão de interesse público, independentemente da retirada da reclamação" (Opuz vs. Turquia, § 145)" (Rosa Weber, ADC 19, p. 27).

A ambivalência se coloca, portanto, como chave para entender as condições de possibilidade dos atos de fala que se inscrevem nos votos dos Ministros sobre as suas respectivas preocupações com a necessária fundamentação das decisões por parte do STF e os silenciamentos sobre as fragilidades evidentes nos processos decisórios e nas práticas "da corte". Ao mesmo tempo que citam jurisprudência "estrangeira" com a naturalidade de quem sabe como se organiza um acórdão em uma corte internacional ou demais "importantes" cortes constitucionais ${ }^{17}$, os ministros não veem problema maior no campo argumentativo no STF. Na frente do espelho - do próprio espelho, mas também em rede nacional de televisão -, performam-se como "antenados" com as decisões e práticas de outros tribunais constitucionais "importantes", seguindo quase sempre uma tendência internacional em temas de grande repercussão, enquanto mantêm em aberto o campo

\footnotetext{
${ }^{17}$ A Corte Europeia de Direitos Humanos, a Corte Interamericana de Direitos Humanos, bem como a Corte Constitucional Alemã, são exemplos de cortes que dividem seus acórdãos em duas grandes partes. Na primeira parte, onde cada parágrafo é numerado a fim de facilitar a citação, tem-se a posição da corte ("the Court's Assessment"), em que é impossível rastrear qual ministro foi responsável pela redação do texto. $\mathrm{Na}$ segunda parte, tem-se os votos divergentes ("dissenting opinion") e os votos concorrentes ("concuring opinion"). A Corte Constitucional Italiana, ao contrário, "veta" qualquer personalização da decisão, impedindo que no acórdão conste qualquer aceno às posições vencidas, seja no campo argumentativo ("concuring opinion"), seja no campo dispositivo ("dissenting opinion").
} 
argumentativo, podendo, a cada julgado, recolocar todos os argumentos sobre a mesa, sem nenhum tipo de amarra ou mesmo de constrangimento (Rodriguez, 2013). É nesta ambivalência que devemos ler "as angústias" que vão no fundo da alma do Ministro Gilmar Mendes, quando do julgamento da ADI 4424 referente à constitucionalidade de alguns dispositivos da Lei Maria da Penha:

\begin{abstract}
Mas quero realmente compartilhar as angústias que vão na minha alma porque, primeiro, a própria fundamentação, e é fundamental que Corte Constitucional - diferentemente do legislador -, nós temos que dizer qual é o fundamento da inconstitucionalidade. Não pode ser um fundamento espiritual. Não pode ser, como eu disse, em outro momento, porque a lei é boa e agora o legislador optou por um modelo eventualmente, na minha visão, um tanto quanto pior. O legislador terá as suas razões para fazer as eleições (Gilmar Mendes, ADI 4424, p. 71).
\end{abstract}

Não se trata, como buscamos demonstrar, de uma questão menor em nenhum Estado liberal, pois o debate sobre a necessidade de justificação está no coração da engenharia do pacto democrático, nos termos da teoria liberal. Estamos em uma democracia, dizem os liberais, porque os juízes, apesar de não terem sido eleitos, decidem com base nas leis que foram aprovadas pelo Parlamento, ou na Constituição, que foi aprovada pelo poder constituinte e que instituiu os poderes constituídos, entre eles, o próprio Poder Judiciário.

A violência desta operação escancara os múltiplos fios através das quais são tramadas e travadas as relações e dinâmicas de poder no tribunal. Só porque as dinâmicas são estas, é possível ter documentado que a Ministra Cármen Lúcia, segundo suas próprias palavras e em tom de desabafo, "não é das que mais fala" e que, entretanto, no julgamento da constitucionalidade da Lei Maria da Penha, fez uma intervenção muito pessoal do sofrimento por que ela passou. Só porque a violência é escancarada é que podemos questionar as frequentes interrupções que o Ministro Marco Aurélio de Mello se autoriza a fazer nas falas da Ministra Cármen Lúcia, inclusive de cunho sexual:

A SENHORA MINISTRA CÁRMEN LÚCIA - Acho que a preocupação de Vossa Excelência procede, em especial por todo o seu talento, mas tenho a impressão que nós temos que completar mudanças no espaço público em que escutávamos "em briga de marido e mulher, ninguém mete a colher". E há um soneto do Drummond que diz: "O que se passa na cama é segredo de quem ama". É bem certo que quem bate não ama. Então, não valeria o soneto.

O SENHOR MINISTRO MARCO AURÉLIO (RELATOR) - Depende do que se passa na cama!

A SENHORA MINISTRA CÁRMEN LÚCIA - Se for violência, o Estado entra, e 
esta é a grande mudança. Acabou a história de achar que, porque as coisas se passam entre quatro paredes, o Estado não pode intervir" (ADI 4424, pp. 65$66)$.

No julgamento da $A D C$ 19, julgada no mesmo dia também pelo plenário da corte, e sob a relatoria do Ministro Marco Aurélio de Mello, há uma outra interrupção que gostaríamos de fazer notar:

A SENHORA MINISTRA CÁRMEN LÚCIA - Tenho absoluta convicção ou convencimento, pelo menos, de que um homem branco, médio, ocidental, jamais poderá escrever ou pensar a igualdade ou a desigualdade como uma de nós, porque o preconceito passa pelo e no olhar. Uma de nós, ainda que dispondo de um cargo titularizando um cargo, que nos dá, às vezes, até necessidade de uso de um carro oficial, vê o carro de quem está ao lado, um olhar diferenciado do que se ali estivesse sentado um homem. Porque, na cabeça daquele que passa, nós mulheres estamos usurpando a posição de um homem, e isso é a média, não de uma pessoa que não tenha tido a oportunidade de compreender o mundo em que vivemos ...

O SENHOR MINISTRO MARCO AURÉLIO (RELATOR) - Pela maledicência, imagina-se, no carro, uma "dondoca".

A SENHORA MINISTRA CÁRMEN LÚCIA - Sim, a esposa de alguém que deve estar trabalhando enquanto ela está indo fazer compras. Isso não significa que o preconceito não acabe, porque já mudou muito. Eu conto aqui, e o Ministro Luiz Fux acaba de dizer, que há uma diferença entre mulheres violentadas ou não violentadas. Acho que não, Ministro. Onde houver, enquanto houver, uma mulher sofrendo violência neste momento, em qualquer lugar deste Planeta, eu me sinto violentada (ADC 19, p. 44).

A interrupção da fala da Ministra, junto à mobilização da categoria "dondoca", escancara as relações de poder e de representação de masculinidades e feminilidades no Supremo, dissimulando em denúncia social o que, na verdade, sobra em reificação dos papéis de gênero. Cármen Lúcia está no "andar de cima", e narra os sofrimentos de uma mulher branca de classe média alta em posição de poder. Até hoje, nunca foi nomeada uma Ministra negra para a vaga no STF.

No julgamento da RCL 2040, conhecido como caso Glória Trevi, alguns anos antes, o sobre a possibilidade de imposição de exame de DNA sobre placenta contra a vontade da mulher, a decisão foi tomada por dez ministros homens e uma mulher, a Ministra Ellen Gracie, cujo voto não foi anexado ao acórdão. Ali, o tribunal impôs exame de DNA forçado na placenta de Glória Trevi, a partir de questionamentos sobre o 'status' da placenta - seria "lixo biológico ou não?" -, bem como alguns votos que sopesaram prevalecer a dignidade de policiais e da própria instituição policial, mesmo inexistindo 
representação da vítima por crime de estupro, ou representação de policiais por crime de calúnia contra Glória. Como diz a canção, é um desmascaro, singelo grito, e o rei está nu, mas nós despertamos porque tudo cala frente ao fato de que o rei é mais bonito nu.

2. Singelo grito: disputas sobre minorias, vulnerabilidades e vítimas

Já há algumas décadas, bastante antes de o Supremo Tribunal Federal se converter em objeto de nossas preocupações, os estudos de gênero se vêm confrontando com o Sistema de Justiça e se debruçando analiticamente sobre autos judiciais. No Brasil, as demandas em torno do problema da "violência conjugal" ou da "violência doméstica e familiar", que historicamente ocuparam as pautas feministas (Facchini e Ferreira, 2016; Machado, 2010) e levaram à promulgação da Lei Maria Penha em 2006, oportunizaram àquele campo de pesquisas uma atenção singular às dinâmicas próprias ao Poder Judiciário, a seus agentes e conflitos, e engendraram um repertório metodológico dos mais interessantes para a análise de práticas e narrativas judiciais. Referência fundamental para esses estudos, o trabalho seminal da antropóloga Mariza Corrêa, "Morte em Família"18, influenciou decisivamente um significativo conjunto de pesquisas sobre violência de gênero ${ }^{19}$ e nos ofereceu ferramentas imprescindíveis para o tratamento analítico de autos judiciais.

Segundo Corrêa (1983), autos judiciais condensam diferentes e conflitivas versões acerca de determinados "atos", processados através de um aparato jurídico que serve de mediador entre acontecimentos e os transforma, excluindo ou incluindo seus elementos em resposta a regras específicas do funcionamento daquele aparato. Os autos judiciais, portanto, não permitem acesso aos atos, aos fenômenos sociais, aos sujeitos

\footnotetext{
18 "Morte em família: representações jurídicas de papeis sexuais" foi publicado originalmente pela Editora Graal em 1983. O livro, contudo, derivou da dissertação de mestrado em Ciências Sociais defendida por Mariza Corrêa ainda em 1975 junto à Universidade Estadual de Campinas, sob a orientação de Verena Stolcke. Sobre a relevância de "Morte em família" para gerações de feministas e os estudos de gênero e sexualidade no Brasil, ver Gregori, 2018. Para um dimensionamento do impacto da obra de Mariza Corrêa na antropologia, nas ciências sociais e nos estudos de gênero no país, conferir o dossiê organizado por Pontes e Gregori (2018), em homenagem a Mariza Corrêa, para o número 54 dos Cadernos Pagu.

19 Nas plataformas de busca on-line de publicações acadêmicas, como o Google Scholar, há centenas de menções a "Morte em Família", o que já estima a intensidade da repercussão do livro de Corrêa (1983) na literatura. Desse rico e diverso conjunto de trabalhos escritos em diálogo com "Morte e família", sugerimos especialmente a leitura de Gregori (1993), Debert e Gregori (2008), Sarti (2011), Pasinato (2011), Nadai (2012), Efrem Filho (2017b; 2018), Almeida e Marachini (2017), Veiga (2018) e Zamboni, Oliveira e Nascimento (2019).
} 
que os operam, ao que de fato acontece ou aconteceu, senão aos atos narrativos de reconstituição e disputa acerca daqueles atos e sujeitos. É por isso que, de acordo com Mariza Corrêa (1983), os atos se encontram em suspensão nos autos e se põem ordenados como em uma "fábula", a qual se obedece a um plano já traçado, que corresponde àquelas regras específicas do campo jurídico, e deve autorizar uma "moral da história" ao final, também se abre à flexibilização desse plano conforme os conflitos protagonizados pelos agentes judiciais.

As fábulas a que Corrêa (1983) se dedica, relativas a assassinatos conjugais praticados por homens e mulheres levados a julgamento pelo tribunal do júri, podem permitir um final de absolvição ou condenação, majoração ou minoração das penas, a depender da adequabilidade de suas personagens, sobretudo a vítima e o algoz, a certas convenções morais de gênero e de sexualidade, ao que se espera de uma "boa mãe" ou de um "bom pai", por exemplo. A seu tempo, as fábulas a que nós nos dedicamos neste texto, nas quais atuam os ministros do Supremo Tribunal Federal diante de controvérsias públicas, podem permitir um final de reconhecimento ou sonegação de direitos, de conformação ou denegação de sujeitos, a depender do quão bem suas personagens correspondam ou não àquelas convenções morais e de como os ministros atuam nas disputas em torno da constituição dessas personagens. Do que lemos dos autos judiciais de que nós aqui nos ocupamos, sobressaem-se nessas disputas dois elementos notáveis: a constituição de "minorias" ou "vulneráveis" a serem protegidos e a consubstanciação de "vítimas" como sujeitos de direitos.

A aparição de minorias nos votos dos ministros do Supremo Tribunal Federal alude, ao menos em parte, às teorias do constitucionalismo democrático e àquilo que, conforme essas teorias, consistiria numa das características basilares de uma corte constitucional, a sua função contramajoritária (Kelsen, 2003; Waldron, 2009; Bellamy e Castiglione, 1997). De acordo com Leonardo Avritzer e Marjorie Marona, "a tradição liberal relaciona o constitucionalismo à estabilidade" (2014, p. 71), do que se depreende que, para essa tradição, os tribunais constitucionais buscariam preservar um conjunto de normas contra a discricionariedade, a transação de interesses ou aquilo que a ministra Cármen Lúcia chamou de "emoções populares momentâneas", quando do julgamento da ADI 3510, a ação a respeito da constitucionalidade das pesquisas com células-tronco embrionárias. Em seu voto favorável às pesquisas, Cármen Lúcia notou: 
Ademais, não imagino que um cidadão democrata cogite querer um juizPilatos dois mil anos depois de Cristo ter sido crucificado porque o povo assim queria. Emoção não faz direito, que é razão transformada em escolha jurídica. Quantos Cristos a humanidade já não entregou segundo emoções populares momentâneas? E quem garante quem será o próximo, que poderá sofrer uma injustiça, evitada pelo que o leigo, às vezes, considera ou apelida ser apenas uma "firula legal"? (Cármen Lúcia, ADI 3510, p. 329).

A função contramajoritária das cortes constitucionais, respeitada por um "cidadão democrata" que rejeitaria a morte de mais um Cristo, pressuporia assim a competência dos julgadores para o exercício da racionalidade, da técnica ou do direito, exercício este contrastado às emoções, aos interesses, à ignorância, a tudo aquilo associável às noções de povo e política. Tal contraste reproduz, portanto, o esforço de edificação de fronteiras característico aos processos de Estado e à configuração da própria ideia de Estado como um ente, da qual participa a separação entre direito e política. Não é difícil perceber que esse contraste se realiza através de uma fabulação tramada em relações desiguais de gênero e de sexualidade, em performances de masculinização e feminização. Marcada pelos "dualismos" de que fala Anne FaustoSterling (2001), essa fabulação apresenta a figura de um emocional e irascível "outro" - o povo, a política - distinguindo-o da figura de um estável "eu" - o Supremo, o "cidadão democrata" - tendente a decidir pela razão e a transformá-la em "escolha jurídica", se nos valemos das palavras da ministra Cármen Lúcia. Entretanto, também não é difícil perceber, nessa fabulação característica às teorias do constitucionalismo democrático, os dualismos de gênero são reciprocamente produção da raça, racialização. É que esse "outro" excessivamente dominado por emoções momentâneas e incapaz de decisão racional é, também, aquele incapaz de entendimento, aquele que não conhece ou compreende, "o leigo" cujas capacidades intelectivas são postas sob suspeita ${ }^{20}$.

De certo modo, portanto, a aparição de minorias nos votos dos ministros do Supremo relaciona-se a um contexto de desigualdades raciais, de gênero e de sexualidade, que sustêm narrativamente a alegada função contramajoritária das cortes constitucionais. Contudo, se as fábulas que compõem os autos das ações judiciais atinentes a controvérsias públicas de gênero e sexualidade costumam seguir o plano dramático de criação de um "outro" generificado e racializado, tal plano não deixa de estar aberto aos diferentes engajamentos dos agentes que o disputam, como já havia

20 Para análise das recentes produções acadêmicas brasileiras que se voltam a raça, sexualidade e gênero, ver Moutinho, 2014. 
percebido Mariza Corrêa (1983) no tocante aos autos de homicídios conjugais. É o que acontece, por exemplo, quando Luiz Fux resolve admitir publicamente que "por debaixo da nossa toga - não é Ministro Ayres? - também bate o coração de um homem" (ADPF 132, p. 76).

Esta frase do ministro Luiz Fux foi dita durante o julgamento da ADPF 132 e da ADI 4277, as duas ações sobre o reconhecimento das uniões estáveis entre pessoas do mesmo sexo, e em diálogo espontâneo com Carlos Ayres Britto, o ministro relator de ambas as ações. Ela, a frase, põe em xeque a dicotomia entre razão e emoção manejada pela ministra Cármen Lúcia quando do julgamento da ADI 3510 e basilar para a tradição liberal do constitucionalismo. Isto porque o homem cujo coração bate sob a toga do ministro da Suprema Corte brasileira, reconhecendo-se emocionado em meio a um julgamento que haveria fundido "paixão e razão", entendeu "importante deixar fluir a voz do coração de um magistrado em relação à análise dessa questão tão sensível para a sociedade" (ADPF 132, p. 76). Após anunciar uma homenagem ao então advogado Luís Roberto Barroso, que atuava na sessão como representante do estado do Rio de Janeiro, autor da ADPF 132, o ministro Luiz Fux definiu o ato de decisão judicial como um amálgama entre a razão e o sentimento: "e não é por outra razão que a própria sentença significa aquilo que o juiz sentiu, aquilo que é o sentimento do juízo" (ADPF 132, p. 76).

A priori estranha ao regular apego jurídico à razão, a proclamação do "sentimento do juízo" adquire sentido e enseja efeito retórico num julgamento em que palavras como afeto, amor e felicidade foram obstinadamente repetidas nos votos dos ministros e vinculadas ao objeto de suas decisões, as uniões estáveis. Não à toa, Ayres Britto ratifica a afetualização dessas uniões e assim define a chamada "união homoafetiva": "uma união essencialmente afetiva ou amorosa, a implicar um voluntário navegar emparceirado por um rio sem margens fixas e sem outra embocadura que não seja a confiante entrega de um coração aberto a outro" (ADPF 132, p. 23). O cenário narrativo judicial proporcionado pelo julgamento da ADPF 132 e da ADI 4277 admitia e impulsionava uma gramática de emoções através da qual se constituía direitos e, inclusive, a minoria que se pretendia proteger e cujos direitos se queria reconhecer: os "homoafetivos".

Objeto de diferentes análises na literatura (Coacci, 2015; Rinaldi, 2014; Coitinho Filho e Rinaldi, 2018; Efrem Filho, 2014), a categoria "homoafetivos" parece resultar de jogos de aquisição de legitimidade, de processos de dessexualização, naturalização ou 
reprivatização da sexualidade, assim como da reafirmação de normatividades e moralidades, do "bom sexo" ou de determinados modelos de organização familiar. Ao que nos interessa mais detidamente neste texto, porém, importa reter que os "homoafetivos" operam, nos votos dos ministros, como a identidade da personagem cujos contornos tornam a fábula palatável. Os "homoafetivos" condensam uma "população", um grupo social imaginariamente demarcável, um conjunto pretensamente minoritário de pessoas, enfim, a minoria fundamental ao desenlace da função contramajoritária do Supremo Tribunal Federal. A partir deles, em sua defesa, os ministros podem agir - e, como se sabe, agiram ${ }^{21}$.

Em parte desses autos judiciais relativos a controvérsias públicas de gênero e de sexualidade, portanto, minorias constituem condição de possibilidade para a ação dos ministros do STF. Inclusive para as disputas que os ministros travam em nome dessas minorias e sobre sua identidade, arquitetando-a mais ou menos sexualizada ou afetualizada, mais ou menos conformável a convenções morais, mais ou menos delimitável a um grupo populacional que, nas palavras do ministro Celso de Mello durante o julgamento da ADO 26 e do MI 4733, "sofrem os efeitos perversos do preconceito, da discriminação e da exclusão jurídica" (ADO 26, p. 142). Como explicado, páginas atrás, essas duas ações tratavam da criminalização da homofobia e da transfobia. Em seu voto como relator da ADO $26^{22}$, Celso de Mello enfatizou que aquele caso "põe em relevo a função contramajoritária do Poder Judiciário no Estado Democrático de Direito, considerada a circunstância de que as pessoas transgêneros representam parcela minoritária da população" (ADO 26 e MI 4733, p. 142).

\footnotetext{
21 Em 04 e 05 de maio de 2011, respondendo aos anseios do Movimento LGBT e de parcela relevante dos movimentos sociais e das esquerdas brasileiras, inclusive os nossos, os ministros do STF reconheceram, por unanimidade, a constitucionalidade das uniões estáveis entre pessoas do mesmo, as tais "uniões homoafetivas". E embora tenha havido divergência entre os ministros sobre a possibilidade de as "uniões homoafetivas" serem conversíveis em casamento - Gilmar Mendes e Ricardo Lewandowski discordavam dessa possibilidade -, pouco mais de dois anos após a decisão dos ministros da corte, em 14 de maio de 2013, os membros do Conselho Nacional de Justiça (CNJ) publicaram a Resolução no 175, que dispunha sobre "habilitação, celebração de casamento civil, ou de conversão de união estável em casamento, entre pessoas do mesmo sexo". Com a resolução, os cartórios se tornaram impedidos de recusar pedidos de casamento e conversão. Uma matéria do site do CNJ, publicada em 09 de maio de 2017, informava que "ao menos 15 mil casamentos homoafetivos foram feitos no Brasil" no período desde a publicação da Resolução no 175 . Para análise da divergência dos ministros Gilmar Mendes e Lewandowski, conferir Efrem Filho, 2014. Para a matéria do CNJ sobre os casamentos, ver: https://www.cnj.jus.br/lei-sobre-casamento-entre-pessoas-domesmo-sexo-completa-4-anos/

22 A Ação Direta de Inconstitucionalidade por Omissão (ADO) 26 foi ajuizada pelo Partido Popular Socialista (PPS) em face do Congresso Nacional e, como dito, teve o ministro Celso de Mello como relator. Por sua vez, o Mandado de Injunção (MI) 4733 foi ajuizado pela Associação Brasileira de Gays, Lésbicas, Travestis, Transexuais e Intersexos (ABGLT) também contra o Congresso Nacional e contou com o ministro Edson Fachin como seu relator.
} 
Posturas similares a esta de Celso de Mello junto à ADO 26 se multiplicaram também no julgamento da ADI 4275, a ação a respeito da alteração de registro civil de travestis e transexuais"23. O ministro Gilmar Mendes, por exemplo, observou que "nós estamos a falar, realmente, do reconhecimento do direito de minorias, de direitos fundamentais básicos" (ADI 4275, p. 141). Já a ministra Rosa Weber advertiu que a proteção do direito à identidade de gênero não significa "imposição de restrição na liberdade ou autonomia dos demais indivíduos, integrantes da opinião pública majoritária da sociedade, mas sim um limite à invasão na esfera individual dessas pessoas que integram um grupo minoritário e estigmatizado pela comunidade política e jurídica" (ADI 4275, p. 82). Por sua vez, o ministro Luís Roberto Barroso, após proclamar que "nós estamos escrevendo uma página libertadora para um dos grupos mais marginalizados e mais estigmatizados dentro da sociedade" (ADI 4275, p. 35), asseverou contundente que "e, quando o sentimento majoritário não seja esse, uma razão humanista deve se impor sobre o senso comum majoritário e fazer a História avançar" (ADI 4275, p.50) - sim, com "H” maiúsculo.

Como visto, os ministros do Supremo Tribunal Federal podem prescindir da presunção da pureza da razão desde que ancorados em uma minoria que justifique suas ações. Por isso, a dicotomia entre razão jurídica e emoção popular traçada por Cármen Lúcia no julgamento da ADI 3510 se fragiliza diante dos votos dos ministros Luiz Fux e Ayres Britto - e não apenas dos deles - junto às ações sobre as "uniões homoafetivas", a ADPF 132 e a ADI 4277. Em diferentes contextos narrativos, a razão a que precisam recorrer os ministros para autorizar sua competência decisória se mescla a outros princípios jurídicos ou expedientes retóricos, como é o caso do humanismo da mencionada "razão humanista" de Luís Roberto Barroso. Flexibilizada a razão aqui ou ali, porém, os ministros permanecem atuando em defesa de minorias ameaçadas por uma maioria, que embora não possa ser sempre definida como emocional ou irracional, porque afinal importa "deixar fluir a voz do coração de um magistrado", continua constituindo-se como o "outro" do "cidadão democrata", uma alteridade preconceituosa e "intolerante" contra a qual os ministros devem decidir e fazer história²4.

\footnotetext{
${ }^{23}$ Neste mesmo dossiê publicado na Direito \& Práxis, o instigante artigo de Thiago Coacci (2020) analisa as condições de possibilidade da decisão proferida no acórdão da ADI 4275 e ressalta as diferenças entre essa decisão e o pedido inicial da ação, retraçando as alterações científicas e jurídicas sem as quais a decisão não seria tomada da maneira como ocorreu.

${ }^{24} \mathrm{Em}$ seus votos, os ministros mencionam o preconceito e a intolerância com alguma frequência. Apenas a título de exemplo: no julgamento da ADPF 132 e da ADI 4277, o ministro Luiz Fux alegou que "o homossexual,
} 
Dentre os casos judiciais implicados em controvérsias públicas de gênero e de sexualidade, a noção de minoria é mais abertamente acionada quando do julgamento das ações que concernem a direitos relativos à diversidade sexual e de gênero, ou seja, quando as minorias em questão podem ser compreendidas como LGBTIs. É o que ocorre nos acórdãos das ações sobre as uniões estáveis entre pessoas do mesmo sexo (ADPF 132 e ADI 4277), a criminalização da homofobia e da transfobia (ADO 26 e MI 4733) e a alteração de registro civil de travestis e transexuais (ADI 4275). Entretanto, por outro lado, a palavra "minoria" sequer é mencionada nos acórdãos sobre a constitucionalidade de dispositivos da Lei Maria da Penha (ADC 19), a dispensa de representação da vítima em casos de lesões corporais de natureza leve, em situação de violência doméstica e familiar contra a mulher (ADI 4424), e a substituição de prisão preventiva por prisão domiciliar nos casos de mulheres presas gestantes ou mães de crianças de até 12 anos ou de pessoas com deficiência (HC 143641).

Nesses três últimos casos judiciais, as minorias perdem espaço para os vulneráveis na estruturação das condições de possibilidade para a ação dos ministros do STF. O voto de Celso de Mello junto à ADPF 54, a ação sobre o aborto de fetos anencéfalos, contudo, talvez indique algum caminho hermenêutico para essa mudança. Logo após apontar a hostilidade do Poder Legislativo, "certamente influenciado por valores e sentimentos prevalecentes na sociedade brasileira", para abordar problemas como o do aborto naquelas circunstâncias, o ministro Celso de Mello passou a argumentar:

Tal situação culmina por gerar um quadro de submissão de grupos vulneráveis à vontade hegemônica da maioria, o que compromete, gravemente, por reduzi-lo, o próprio coeficiente de legitimidade democrática da instituição parlamentar, pois, ninguém o ignora, o regime democrático não tolera nem admite a opressão, por grupos majoritários, da minoria, definida tal expressão à luz do critério da vulnerabilidade das mulheres, que pode ser social, econômica e jurídica (Celso de Mello, ADPF 54, p. 360).

Celso de Mello, desse modo, define "minorias" de acordo com o que chama de "critério da vulnerabilidade das mulheres". Não podendo ser numericamente reportadas como um grupo minoritário, as mulheres tornam-se minoria à medida de sua vulnerabilização. Este movimento de identificação das mulheres através de sua

em regra, não pode constituir família por força de duas questões que são abominadas pela nossa Constituição: a intolerância e o preconceito" (ADPF 132 e ADI 4277, p. 78); noutro momento, quando de seu voto junto à ADI 4275, a ministra Cármen Lúcia argumentou que "a Constituição dispõe sobre igualdade. Entretanto, a igualdade é uma conquista permanente, porque continua havendo intolerância, discriminação, preconceito, todas as formas de manifestação, expressa ou velada" (ADI 4275, p. 145). 
vulnerabilidade, todavia, repete-se em diferentes momentos dos autos de que estamos tratando. Em seu voto como relator da ADC 19, o ministro Marco Aurélio nota que "a mulher é eminentemente vulnerável quando se trata de constrangimentos físicos, morais e psicológicos sofridos no âmbito privado" (ADC 19, p. 14). Já o ministro Cezar Peluso, em seu voto junto à mesma $A D C$, assegura que a Lei Maria da Penha representou uma estratégia normativa para a aplicação do princípio da igualdade, "sobretudo numa situação em que a vulnerabilidade da mulher é manifesta, e, por isso mesmo, pediria, como pediu, a intervenção do ordenamento jurídico a seu favor" (ADC 19, p. 71).

A identificação da mulher como vulnerável sobressaiu-se, no entanto, nas discussões acerca da dispensa de representação da vítima em casos de lesões corporais de natureza leve, em situação de violência doméstica e familiar contra a mulher, por ocasião do julgamento da ADI 4424. Em artigo também publicado neste dossiê da Direito \& Práxis, Marília Montenegro Pessoa de Mello e Manuela Abath Valença (2020) explicam que "no acórdão dessa ação, a palavra 'proteção' aparece mais de cinquenta vezes e a grande ideia veiculada nos votos é a de que a mulher não poderia fazer a escolha sobre processar ou não o agressor, dada a sua condição de vulnerabilidade". No centro das fundamentações dos votos da maioria dos ministros junto à ADI 4424 está, portanto, o pressuposto da vulnerabilidade da mulher, que a impediria de exercitar a própria vontade sem correr o risco de vulnerabilizar-se ainda mais. Daí a posição do ministro Marco Aurélio, relator da ação: "Exigir da mulher que represente não é protegê-la, mas deixá-la vulnerável - mais vulnerável ainda" (ADI 4424, p. 24).

O acórdão da ação acerca da substituição de prisão preventiva por prisão domiciliar nos casos de mulheres presas gestantes ou mães de crianças de até 12 anos ou de pessoas com deficiência, o HC 143641, menciona "grupos sociais vulneráveis" desde a sua ementa. Os votos dos ministros também arregimentam a noção de vulnerabilidade diversas vezes, relacionando-a às mães em situação de prisão provisória e a seus filhos. Porém, neste caso, chama atenção especialmente o modo como os ministros, além de identificarem as personagens da fábula processual como vulneráveis, acionam a vulnerabilidade para justificar uma mudança na jurisprudência da corte. É que, como explicou o ministro Dias Toffoli em seu voto no julgamento do HC 143641, os ministros do STF não admitiam Habeas Corpus em formato coletivo. Alegavam, por exemplo, que a excessiva generalidade e a indeterminação dos "pacientes" e das "autoridades coatoras" 
esbarravam nas normas existentes, inclusive constitucionais, sobre os requisitos para a impetração do Habeas Corpus.

A vulnerabilidade daquelas mães e crianças reiteradamente tecida nas páginas do HC 143641, entretanto, pareceu incitar uma nova interpretação sobre o formato do Habeas Corpus. Foi assim que Ricardo Lewandowski, o ministro relator do HC em questão, aduziu que "a ação coletiva emerge como sendo talvez a única solução viável para garantir o efetivo acesso destes à Justiça, em especial dos grupos mais vulneráveis do ponto de vista social e econômico" (HC 143641, p. 24). Na mesma linha, o ministro Dias Toffoli, depois de reconhecer já haver decidido contra a admissão de HC coletivo, ponderou que sua posição anterior deveria ser repensada, "justamente porque nossa Constituição prevê que a lei não excluirá da apreciação do Poder Judiciário lesão ou ameaça a direito (CF, art. 5o, inciso XXXV), sobretudo dos mais vulneráveis, cujo tratamento coletivo desempenharia a relevantíssima função de promoção efetiva de acesso à justiça" (HC 143641 , p. 74). Curiosamente, em 19 de fevereiro de 2018, um dia antes de os ministros da segunda turma do STF decidirem sobre o referido HC 143641, o ministro Alexandre de Moraes, do mesmo Supremo, assinou decisão que negou seguimento a um Habeas Corpus coletivo ${ }^{25}$ relacionado a presos que se encontram em estabelecimentos penais federais há mais de dois anos. Por "razões" indiscerníveis, mas cuja incompreensibilidade sugere relações de gênero, algumas vulnerabilidades produzem mais efeitos que outras quando paginadas nos autos do tribunal...

Laura Lowenkron tem argumentado que "consentimento" e "vulnerabilidade" são "conceitos-chaves e complementares para a compreensão dos regimes contemporâneos de regulação jurídica das sexualidades e das sensibilidades sociais e políticas em relação à violência" (2015, p. 225). Voltada sobretudo aos problemas do tráfico de pessoas e do abuso sexual infantil, Lowenkron conclui que a vulnerabilidade consiste numa categoria - "polissêmica e escorregadia", em seus termos (Idem, p. 228) capaz de dissipar a validade simbólica e jurídica do consentimento, conclusão esta que, com os devidos cuidados, nós poderíamos replicar na análise dos votos dos ministros do STF junto à ADI 4424, antes discutida. Seguindo Lowenkron (2015), seria possível apreender, por exemplo, como a presumida vulnerabilidade da mulher se faz recurso discursivo suficiente para desabilitar, nos autos daquela ação, sua capacidade de decisão 
(no caso, sobre processar ou não um marido, um companheiro ou um filho que the poderia haver infligido uma lesão corporal de natureza leve).

Contudo, importa-nos aqui mais detidamente perfilar, em estreito diálogo com Lowenkron (2015), as formas como, nos casos atinentes a controvérsias públicas de gênero e de sexualidade sob nossa análise, a vulnerabilidade a partir da qual os ministros engendram e justificam sua própria ação se articula à figura da vítima e a uma gramática de sofrimento. Como dissemos anteriormente, minorias e vulneráveis costumam performatizar personagens a partir das quais os ministros agem, decidem e participam da construção das fábulas nos autos judiciais. No conjunto desses autos mais diretamente ligados a direitos atinentes à diversidade sexual e de gênero, nos quais os LGBTs emergem narrativamente, as minorias se encontram explicitamente presentes, como já notamos. Em alguns desses autos "a respeito de LGBTs", os ministros quase não empregam o substantivo vulnerabilidade, o adjetivo vulnerável ou seus correlatos, como é o caso dos autos da ADPF 132 e da ADI 4277, julgadas em conjunto, sobre as "uniões homoafetivas", ou dos autos da ADI 4275, sobre a alteração de registro civil de travestis e transexuais. Em parte desses autos, por outro lado, os ministros utilizam aqueles termos saturadamente, como ocorreu com o julgamento da ADO 26 e do MI 4733, também em conjunto, sobre a criminalização da homofobia e da transfobia. Por sua vez, como explicamos, minorias desaparecem dos acórdãos da ADI 4424 e da ADC 19, ambas relacionadas à violência doméstica e familiar, e do HC 143641, sobre mães em situação de prisão provisória. 0 desaparecimento das minorias nesses acórdãos é recíproco, porém, à assunção da vulnerabilidade, como também explicado. Em praticamente todos esses autos, entretanto, minorias e vulneráveis sofrem e, no mais das vezes, com maior ou menor intensidade, são referidos como vítimas.

O acórdão das ações sobre a criminalização da homofobia e da transfobia, a ADO 26 e o MI 4733, é certamente emblemático do que estamos chamando de gramática do sofrimento e de articulação da figura da vítima para o reconhecimento de direitos e a figuração de sujeitos de direitos. Relator da ADO 26, o ministro Celso de Mello dedicou parte importante do seu voto de 157 páginas a apresentar dados estatísticos, matérias jornalísticas e relatórios de pesquisas sobre casos de violência contra LGBTs no Brasil. Depois de indicar que, no país, LGBTs são tratados "absurdamente, a despeito de sua inalienável condição de pessoas investidas de dignidade e de direitos, como indivíduos destituídos de respeito e consideração", depois de ressaltar como LGBTs são "degradados 
ao nível de quem sequer tem direito a ter direitos, posto que se lhes nega, mediante discursos autoritários e excludentes, o reconhecimento da legitimidade de sua própria existência" (ADO 26 e MI 4733, p. 14), Celso de Mello passou a associar a história da violência contra LGBTs à história da colonização brasileira, "iremos constatar a maneira cruel (e terrivelmente impiedosa) com que as autoridades da Coroa perseguiram e reprimiram os homossexuais" (Idem, p. 30), para então chegar aos números atuais de violência, também trazidos pelos amici curiae ao plenário da corte, dados estatísticos estes que, segundo Celso de Mello, "demonstram que a comunidade LGBT no Brasil é, reiteradamente, vítima das mais diversas formas de agressão motivadas, única e exclusivamente, pela orientação sexual e/ou identidade de gênero dos indivíduos" e comprovam que "o Brasil 'é o campeão mundial desse tipo de crime'” (ADO 26 e MI 4733, p. 37$)^{26}$.

Em seu voto também favorável à criminalização da homofobia e da transfobia, o ministro Luiz Fux relembrou "aquela cena que tanto nos afligiu, diante da proteção constitucional a todos os seres humanos com relação à sua dignidade, à orientação sexual, daquele jovem que quebrou uma lâmpada no rosto de jovens integrantes da comunidade LGBT" (ADO 26 e MI 4733) ${ }^{27}$. No mesmo julgamento, a ministra Rosa Weber rememorou as punições que Oscar Wilde e Tchaikovsky sofreram em razão de sua "homossexualidade". Já o ministro Marco Aurélio, em seu voto, ao reconhecer a persistência de grave quadro de discriminação no Brasil e observar "a violência diuturnamente dirigida a homossexuais e transgêneros, de todo incompatível com a tradição de tolerância do povo brasileiro no tocante, por exemplo, à diversidade cultural e religiosa" (ADO 26 e MI 4733), voltou a citar os dados de violência constantes nos

${ }^{26}$ Os dados estatísticos citados pelo ministro Celso de Mello em seu voto derivam principalmente dos relatórios anuais do Grupo Gay da Bahia (GGB), que funcionava como amicus curiae naquele julgamento, e do Transgender Europe, organização também mencionada nas alegações do GGB nos autos. Além disso, Celso de Mello se reporta a um relatório submetido pelo Alto Comissário das Nações Unidas para os Direitos Humanos - sobre violência e discriminação motivadas pela orientação sexual ou pela identidade de gênero das pessoas - e aprovado pelo Conselho de Direitos Humanos da ONU; assim como se reporta ao relatório sobre as formas contemporâneas de racismo, discriminação racial, xenofobia e intolerâncias relacionadas, elaborado por um relator especial designado pela Assembleia das Nações Unidas, o qual advertiu sobre a necessidade de os Estados-membros adotarem legislação que criminalize a homofobia.

27 O ministro Luiz Fux se refere ao caso, ocorrido na manhã de 14 de novembro de 2010, do jovem e dos adolescentes que espancaram um rapaz gay na Avenida Paulista, usando uma lâmpada fluorescente como arma. De tão marcante, o episódio deu nome a um "coletivo de artivismo" dedicado ao enfrentamento à violência e à defesa da liberdade do corpo. Para informações sobre o caso e suas consequências judiciais, ver: https://g1.globo.com/sp/sao-paulo/noticia/2018/10/18/jovens-que-agrediram-gay-na-paulista-comlampada-terao-que-pagar-multa-de-r-257-mil.ghtml. Para discussões sobre o coletivo Revolta da Lâmpada, ver Grunvald (2019). 
relatórios do Grupo Gay da Bahia, também referidos pelo ministro Gilmar Mendes, ao lado de dados governamentais decorrentes do Disque 100.

Embora o acórdão do julgamento da ADO 26 e do MI 4733 seja emblemático, como dissemos, do empenho dos ministros na contextura narrativa do sofrimento, da violência e da vitimização, esse empenho assume certas peculiaridades caso a caso. É perceptível, por exemplo, a intensidade de sofrimento atribuída a travestis e transexuais nos autos da ADI 4275, sobre o direito à alteração de registro civil. Nesses autos, os ministros destacam o impacto do estigma na vida de travestis e transexuais, "que conduz muitos cidadãos transgêneros à depressão, à prostituição ${ }^{28}$ e ao suicídio" (ADI 4275, p. 12), de acordo com Marco Aurélio, relator da ação; ou que conduz a vergonha, humilhação, exposição ao ridículo e constrangimento, como designou a ministra Rosa Weber ao se referir à situação gerada pela presença de um indivíduo "com traços, gestos, roupas, cabelos e seios femininos", mas compelido a se apresentar com nome masculino (ADI 4275, pp. 64 - 65). A ministra Cármen Lúcia talvez tenha sido, porém, aquela que melhor sintetizou, em seu voto, a tônica de dor que atravessa aqueles autos. Após descrever uma conversa sua com uma "pessoa transgênero" e de reconhecer as bem maiores dificuldades vivenciadas por alguém que normalmente não conta sequer com o apoio da família de origem - "no seu caso, o seu pai se indigna junto com você" -, Cármen Lúcia asseverou que "há escalas de sofrimento diferentes na vida humana" (ADI 4275, p. 145) e que "ter de viver segundo a aparência que o outro impõe é uma forma permanente de sofrimento" (ADI 4275, p. 147).

O sofrimento também informou os votos dos ministros do Supremo favoráveis à descriminalização do aborto de fetos anencéfalos, na ADPF 54. Nesses votos, todavia, 0 sofrimento resultava da imposição estatal de uma mulher prosseguir com a gravidez de um feto que sabia inviável, o que importaria, nas palavras de Ayres Britto, na "dilacerante dor de ver o produto da sua concepção involucrado numa mortalha" (ADPF 54, p. 264), ou "na dor moral de carregar no seu ventre, durante nove meses, um filho em relação ao qual ela assiste à missa de sétimo dia" (ADPF 54, p. 154), segundo Luiz Fux. O sofrimento

\footnotetext{
28 Nas páginas do acórdão da ADI 4275, a prostituição emerge nos votos do ministro Marco Aurélio, como citado acima, da ministra Cármen Lúcia (p. 148) e, definida como "trabalho sexual", também no voto do ministro Luiz Fux, quem remete a uma pesquisa desenvolvida na Universidade Federal de Minas Gerais, segundo a qual $90 \%$ das travestis e transexuais exercem trabalho sexual no Brasil atualmente (p. 98). Nessas três menções, a prostituição é significada pejorativamente, como dimensão do sofrimento. Para análises a cerca dos conflitos políticos que envolvem prostituição, vitimização e criminalização, conferir: Lowenkron (2015); Piscitelli e Lowenkron (2015), Blanchette e Silva (2005) e Mello (2019).
} 
de que falam esses ministros é tanto físico quanto psíquico, emocional. Ele concerne, por exemplo, ao fato de que "a cabeça do feto portador de anencefalia não consegue se 'encaixar' de maneira adequada na pélvis, o que importa em um trabalho de parto mais prolongado, doloroso, levando, comumente, à realização de cesariana" (ADPF 54, p. 61), como notou o ministro Marco Aurélio, referendando-se em informações da FEBRASGO 29. Mas também concerne a sensações de "choque, angústia, tristeza, resignação, destruição de planos, revolta, medo, vergonha, inutilidade, incapacidade de ser mãe, indignação e insegurança", conforme o mesmo ministro Marco Aurélio, agora mencionando uma pesquisa desenvolvida na Universidade de São Paulo. No limite dos argumentos desses ministros, tal sofrimento é compreendido como "tortura". Esta palavra que, de acordo com Gabriela Rondon $(2020)^{30}$, já se encontrava na petição inicial contrastada à noção de dignidade da pessoa humana, acabou repetindo-se diversas vezes nas fundamentações dos votos dos ministros, como nesta passagem do voto de Ayres Britto: "por isso que levar às últimas consequências esse martírio contra a vontade da mulher corresponde à tortura, a tratamento cruel. Ninguém pode impor a outrem que se assuma enquanto mártir; o martírio é voluntário" (ADPF 54, p. 265).

Com suas singularidades, também as fábulas que perfazem os demais casos com que estamos lidando neste artigo encetam contextos narrativos de sofrimento e violência, a partir dos quais suas personagens podem ser tomadas como vítimas cujos direitos precisam ser reconhecidos. Assim, nos casos atinentes a controvérsias públicas de gênero e sexualidade, minorias e vulneráveis vitimáveis se convertem em sujeitos de direitos sobretudo através de suas minorações, vulnerabilizações e vitimizações. Estas operações, de certo, desvelam-se repletas de riscos. De pronto, porque a conflagração de sujeitos através da definição da vítima tangencia aquilo que Maria Filomena Gregori (1993) chamou de "vitimismo", ou seja, o engendramento de uma vítima excessivamente vítima, essencialmente vítima, impassível de ação e contradição, ou de qualquer existência para além dos limites dessa condição. Depois, porque essa vítima precisa responder, de alguns modos, a convenções morais que ajudam a torná-la a personagem palatável da fábula possível àqueles autos. Essa personagem pode consistir no "homoafetivo" cuja sexualidade é perdida, como indicamos acima, mas também na travesti que deverá livrar-

\footnotetext{
${ }^{29}$ Federação Brasileira das Associações de Ginecologia e Obstetrícia.

${ }^{30} \mathrm{Em}$ artigo também publicado neste dossiê da Direito \& Práxis, Gabriela Rondon (2020) analisa a mobilização, na ADPF 54, do conceito de dignidade da pessoa humana como vedação de submissão à tortura.
} 
se do "sofrimento da prostituição" com a alteração do registro civil e a conquista de certo direito. A sua maneira, essa personagem pode inclusive conformar a mulher que precisa provar-se torturada para conseguir decidir sobre o seu próprio corpo e o futuro de uma gestação.

Esses riscos, claro, não se circunscrevem às disputas travadas nos autos judiciais com que lidam os ministros do Supremo Tribunal Federal. Eles se apresentam com frequência nas lutas por direitos e "justiça" e em parte significativa dos conflitos sociais e processos de Estado com que nós nos preocupamos política e analiticamente (Vianna e Farias, 2011; Lacerda, 2014; Freire, 2015; Efrem Filho, 2017b; Lago, 2019). Nessas lutas e conflitos, a exposição pública do sofrimento e as disputas em torno da legitimidade das vítimas de violência integram a mobilização social e a organização popular e demonstram, sendo assim, que a performatização da vítima tem constituindo o fazer político de movimentos sociais e setores de esquerda, ainda que necessariamente friccionando os riscos em questão, como ocorre quando esses sujeitos se voltam para o Supremo Tribunal Federal, aliados ou não a agentes e setores de Estado, em busca do reconhecimento das uniões estáveis entre pessoas do mesmo sexo, da declaração da constitucionalidade da Lei Maria da Penha, da criminalização da homofobia e da transfobia etc.

Se é verdade que, como afirmamos, minorias e vulneráveis preenchem as condições de possibilidade para ações e decisões dos ministros do Supremo, não deixa de ser verdade que os sujeitos assim performatizados naqueles autos judiciais participam intensamente dos conflitos e mobilizações que levaram os casos à corte e, dessa forma, à sua própria performatização. Exemplos interessantes disso estão nas referências aos dados dos relatórios do Grupo Gay da Bahia no acórdão da ADO 26 e do MI 4733, assim como na assunção da "tortura" no repertório argumentativo dos ministros que votaram favoravelmente à descriminalização do aborto em casos de fetos anencéfalos, junto à ADPF 54. Com isso, queremos dizer que, de certa forma, as minorias e os vulneráveis vitimáveis - ou os sujeitos que reivindicam essas categorias, mobilizados em movimentos sociais ou presentes em seu campo ou arena (Facchini, 2009) - participam das disputas em torno de sua identidade, ainda que, nas narrativas judiciais, sejam ministros quem as constitui, já que são eles quem fala para "fazer a corte falar", como salientamos na primeira seção deste artigo.

É necessário lembrar, além disso, que os ministros nem sempre confluem quando de seu empenho na contextura de narrativas de sofrimento, violência e 
vitimização. Pelo contrário, em alguns desses casos relativos a controvérsias públicas de gênero e sexualidade, ministros protagonizam conflitos internos que, não raro, centramse exatamente na legitimidade ou na ilegitimidade de determinados sujeitos de direitos e, como tal, em sua inteligibilidade como vítima. As divergências dos ministros do STF acerca da descriminalização do aborto de fetos anencéfalos exprimem bem esses conflitos capazes de manter a vítima sob aberta e perversa suspeita. Como explicado acima, os ministros que votaram favoravelmente ao pedido principal da ADPF 54, a descriminalização da chamada "antecipação terapêutica do parto", ativaram imagens de sofrimento e até mesmo o conceito de tortura para justificarem seus votos. Em questão estava a persona da mãe que sofre, portanto.

Entretanto, como Gabriela Rondon (2020) indicou, essa persona foi explicitamente contestada pelo ministro Cezar Peluso, que em seu voto se dedicou a relativizar o sofrimento dessa mãe - "o sofrimento em si não é alguma coisa que degrade a dignidade humana; é elemento inerente à vida humana" (ADPF 54, p. 404) - enquanto alegava a dignidade constitucional plena da vida intrauterina e a impropriedade da analogia com a tortura, visto não haver "sofrimento injusto" no caso, tampouco a possibilidade de responsabilizar o Estado "por dramas que são de responsabilidade exclusiva da conjugação de ato livre dos particulares e de ulterior acaso biológico" (ADPF 54, p. 404). Peluso, porém, interessa notar, não abre mão da gramática do sofrimento ou da articulação da figura da vítima. Pelo contrário, o ministro as desloca para o feto, do que decorre sua preocupação com o que seria "o consequente agravamento do risco de eugenia".

Um outro exemplo de suspeição da inteligibilidade da vítima pode ser encontrado nos votos dos ministros da segunda turma do STF durante o julgamento do HC 143641, aquele sobre a substituição de prisão preventiva por prisão domiciliar nos casos de mulheres presas gestantes ou mães de crianças de até 12 anos ou de pessoas com deficiência. Como falamos anteriormente, os ministros acionaram fartamente a noção de vulnerabilidade em seus votos junto ao Habeas Corpus, modificando até mesmo a jurisprudência do Supremo a respeito da admissibilidade do seu formato coletivo. Ricardo Lewandowski, o ministro relator da ação, investiu narrativamente, por exemplo, na exposição da "realidade em que vivem as mulheres presas, a qual já comportou partos em solitárias sem nenhuma assistência médica ou com a parturiente algemada ou, ainda, sem a comunicação e presença de familiares" (HC 143641, p. 38). Porém, nos interstícios 
do julgamento do HC 143641, travou-se uma disputa de entrelinhas, não de todo anunciada, em torno do sujeito de direitos que se quereria preservar daquelas condições de vulnerabilidade: a mãe ou a criança?

Em seus argumentos, o ministro Lewandowski aglutinou os dois sujeitos, objetivando com a aquela decisão "a proteção da mãe, sobretudo daquela que amamenta" e de "mais de dois mil pequenos brasileirinhos, que estão atrás das grades, com suas mães, sofrendo indevidamente" (HC 143641, p. 60). No entanto, embora referências ao direito à maternidade hajam aparecido também nos votos dos outros ministros, alguns ressalvaram sobretudo a prevalência dos direitos da criança que, para sua garantia, demandaria a substituição da prisão provisória pela prisão domiciliar da mãe. Dentre os votos, o do ministro Edson Fachin foi o que melhor expressou esse dissenso: "Não há dúvidas que as mulheres, mas também os homens presos, nos termos do art. 318, VI, do CPP, têm direito à vida familiar e à reinserção social. O instrumento previsto pelo art. 318 , no entanto, destina-se à avaliação concreta, feita pelo juiz da causa, do melhor interesse da criança" (HC 143641, p. 137).

Com seu posicionamento, Fachin pretendeu que, não restando a discussão centrada nos direitos das mães, mas sim nos direitos das crianças, a prisão domiciliar fosse avaliada de acordo com o interesse da criança em cada caso. Não havendo esse interesse, no caso concreto, não haveria a conversão da prisão provisória em domiciliar. Foi o ministro Dias Toffoli, entretanto, quem chegou mais perto de materializar esse argumento de Edson Fachin ao expor suas suspeitas acerca de determinadas mães, incapazes de fazer cumprir o melhor interesse de seus próprios filhos. Deu-se que, em seu voto, Lewandowski havia consignado que "para apurar a situação de guardiã dos filhos da mulher presa, dever-se-á dar credibilidade à palavra da mãe" (HC 143641, p. 08). Toffoli, por sua vez, discordou da proposta de Lewandowski, sob a alegação de que "existem situações, inclusive, de mulheres que usam dos filhos menores de 12 anos para, de alguma maneira, escamotear o cometimento de crimes. Existem situações extremamente graves" (HC 143641, p. 113). Em resposta sagaz ao ministro Dias Toffoli, Ricardo Lewandowski retrucou-o com uma analogia:

Vossa Excelência me permite? É que não queremos, Ministro Toffoli, permitir novamente aqui a discricionariedade do juiz: "A senhora não é guardiã e tal". No primeiro momento, temos que dar credibilidade, assim como fazemos nos crimes sexuais: A palavra da vítima é muito importante. Se, depois, provar-se que ela não é guardiã, ela perde o benefício. Entretanto, no primeiro 
momento, tem que se dar o benefício da dúvida, em homenagem ao bemestar da criança (Ricardo Lewandowski, HC 143641, p. 115).

Com seu aparte em meio ao voto de Toffoli, assim, Lewandowski atualizou a figura da vítima, comparou a mãe acusada do cometimento de um crime à vítima do crime de estupro, a quem seria necessário dar credibilidade de antemão. Mas a este gesto de Lewandowski nem sempre se assistiu nos julgamentos da corte. Se em 20 de fevereiro de 2018, o HC 143641 teve sua ordem concedida, em 21 de fevereiro de 2002, a cantora mexicana Glória Trevi teve sua reclamação recusada pelos ministros do Supremo Tribunal Federal. Como dissemos no início deste texto, a RCL 2040-1 concerniu ao pedido de Gloria Trevi de que sua placenta não fosse submetida a exame de DNA contra a sua vontade. Presa na sede da Polícia Federal de Brasília durante seu processo de extradição, Trevi teria concedido uma entrevista à revista IstoÉ, na qual se publicou que a sua gravidez resultara de um "estupro carcerário" ocorrido numa das celas da Polícia Federal. A ocorrência do citado "estupro carcerário" foi também noticiada aos ministros do STF, formalmente, através de uma petição da cantora ou de seu advogado.

A confusão gerada em torno da notícia ensejou uma investigação policial e, com ela, a realização voluntária de exames de DNA em 61 homens, entre policiais federais e presos que transitaram pelas dependências da Polícia Federal de Brasília no período. Com esses exames em mãos, o delegado responsável pelas investigações pretendia confrontar o material genético daqueles homens com o material genético do recém-nascido, para enfim saber se algum daqueles policiais ou presos era, de fato, o pai do filho de Glória, quem inclusive sequer se havia apresentado a autoridades policiais como vítima de crime de estupro, do que decorria que ninguém era de fato acusado do seu cometimento ${ }^{31}$. 0 magistrado de primeira instância que acompanhava o inquérito então autorizou o exame sobre a placenta, após o parto que aconteceria em um hospital determinado pela decisão de um ministro do STF, responsável pelo processo de extradição a que Trevi respondia.

\footnotetext{
31 À época dos fatos, o art. 225 do Código Penal previa que o crime de estupro somente se procedia mediante queixa da vítima, a priori, ou mediante representação, se a vítima ou seus pais não pudessem prover as despesas do processo. Segundo o mesmo art. 225, o crime só se procedia mediante ação pública incondicionada se fosse cometido com abuso do pátrio poder, ou da qualidade de padrasto, tutor ou curador. Isto significa que, para haver um inquérito policial ou um processo judicial em razão do "estupro carcerário" que hipoteticamente envolvia Glória Trevi, ela precisaria haver apresentado queixa, coisa que não fez. Sendo assim, o inquérito que existia e levou à decisão sobre o exame de DNA na placenta da cantora não dizia respeito à investigação sobre a ocorrência ou não de crime de estupro. No Brasil, o crime de estupro se tornou objeto de ação penal pública incondicionada em 2018, com a Lei 13718/18.
} 
Mas Trevi, como dito, recusou o exame sob o argumento do respeito ao direito à intimidade e à vida privada, que a fazia não desejar publicizar a paternidade do seu filho.

O icônico - como o chamamos - e curioso caso de Glória Trevi junto ao Supremo Tribunal Federal requereria mais atenção e maior densidade analítica do que conseguiremos dispensar a ele neste texto. Por ora, no entanto, nós gostaríamos de localizá-lo em meio àqueles conflitos acerca da inteligibilidade da vítima de que estamos tratando. Isto porque, ainda que Trevi haja reivindicado perante os ministros do STF a condição de "vítima" - "Ela alega, portanto, ser vítima, e pede a proteção do Tribunal, pois está à sua disposição, para não ser submetida, pela autoridade de outro magistrado, a esse ato contrário à sua vontade" (RCL 2040-1, p. 134), como disse o ministro Néri da Silveira - os ministros do Supremo acabaram transferindo o processo de vitimização para outros sujeitos: em bem menor grau, o próprio filho de Glória Trevi, que estaria sendo privado do seu direito quanto a saber de sua origem genética, como argumentou o procurador da república citado por Néri da Silveira em seu voto; mas sobretudo os policiais federais cuja honra e cuja dignidade estariam ameaçadas com a repercussão daquelas notícias sobre o estupro, como também alegou o procurador.

Estranhamente, portanto, nos autos do acórdão da RCL 2040-1, os policiais federais performatizam a vítima da desonra. Mas não apenas eles. Nos votos dos ministros e, neles, em suas citações a outras autoridades públicas - o delegado, o citado procurador, o juiz e os próprios policiais - a vitimização se estende a mais do que pessoas físicas, ao próprio Departamento de Polícia Federal, segundo Néri da Silveira: “A acusação (...) não só atingiu a honra e dignidade dos policiais federais, alguns referidos nominalmente na imprensa, como acabou por alcançar, também, o Departamento de Polícia Federal, a instituição em si" (RCL 2040-1, p. 134). Além de com a "instituição em si" da Polícia Federal, o Ministro Carlos Velloso demonstrou preocupação com "a imagem do Brasil no campo internacional, que fica, diante da acusação, abalada" (Idem, p. 227).

Parece-nos que esses três exemplos de suspeição ou deslocamento da inteligibilidade das vítimas auxiliam-nos na compreensão dos contextos narrativos e das relações de poder em que a gramática do sofrimento é mobilizada e em que se articula a figura da vítima. Em tais contextos, nos casos judiciais relativos a controvérsias públicas de gênero e sexualidade de que aqui nós nos ocupamos, narrativas de sofrimento, violência e vitimização não estão inexoravelmente destinadas à afirmação de sujeitos, sejam "minorias" ou "vulneráveis", de direitos sexuais e reprodutivos ou daqueles direitos 
relacionados à diversidade sexual e de gênero. Em alguns votos de ministros, ainda que vencidos, e num julgamento inteiro, ainda que antigo, sofrimento, violência e vitimização são ativados narrativamente com vistas ao recrudescimento de processos de Estado de criminalização, de punição e de ratificação de efeitos - e "honras" - de Estado. Enfim, importa ainda notar que a atenção analítica a esses conflitos acerca da inteligibilidade da vítima, de sua suspeição e de seu deslocamento, faz-se importante inclusive para evitar que nós, no ímpeto do exercício da crítica às dinâmicas de vitimização, acabemos recaindo na homogeneização e na entificação do Estado e, dessa forma, reproduzindo uma dimensão tão cruel dos seus efeitos de poder.

\section{Considerações finais}

Normalmente as fábulas imprimem um efeito pedagógico. Elas costumam encerrar-se com uma lição de moral, algo a ser aprendido sobre o certo e o errado, o bom e o mau. $\mathrm{Na}$ fábula do conto de Hans Christian Andersen, aprende-se que a vaidade e a subserviência de monarcas e senhores falham diante da sinceridade da criança. Nas fábulas contadas nos autos judiciais sobre homicídios conjugais, analisadas por Mariza Corrêa (1983), aprende-se sobre a performatização do "bom marido" e do "bom pai", da "boa esposa" e da "boa mãe". Nas fábulas que preenchem os acórdãos do Supremo Tribunal Federal relativos a controvérsias públicas de gênero e sexualidade, aprende-se sobre o sujeito que sofre, o mau "outro" sujeito que the infringe sofrimento, mas sobretudo sobre o bom sujeito que decide. Desnudar analiticamente a fábula - "o rei está nu" - não deixa de consistir num esforço de resistência à sua lição.

Anunciar a nudez do rei, como tentamos insistentemente nas páginas deste artigo, não supõe o desejo de que ele estivesse vestido, tampouco intenciona reproduzir a "sinceridade" da criança, alguma capacidade hipotética de ver algo que mais ninguém possui coragem, liberdade ou desprendimento para ver. O desnudamento das práticas e decisões dos ministros do Supremo Tribunal Federal, da sua recusa em conjurar esforços para produzir a "razão de decidir" de suas tomadas de posição, de suas estratégias de construção de autoridade, do fato de que as páginas dos acórdãos somam votos individuais que servem à compreensão do resultado final de uma votação, mas não ao entendimento de sua justificação etc., ajuda-nos a localizar o Supremo Tribunal Federal e 
seus ministros em sua peculiar e tensa relação com a experiência democrática. Assim, sua nudez é bela - seguindo Caetano novamente, "o rei está nu / mas eu desperto porque tudo cala frente ao fato de que o rei é mais bonito nu" - inclusive porque nos incita a percebê-la e anunciá-la em nossos exercícios analíticos e nos conflitos políticos de que somos parte.

Ademais, a nudez é bela porque invoca as relações de gênero e de sexualidade que preenchem as práticas dos ministros em seus processos decisórios na corte, mas também a relação dos seus ministros com todas essas controvérsias públicas, as quais ocupam crescente centralidade na agenda pública do país. Como sabemos, algumas de suas decisões implicadas em controvérsias públicas de gênero e sexualidade certamente se encontram entre as que mais atraíram atenção para a corte e os próprios ministros. Segundo Joaquim Falcão e Fabiana Oliveira (2013), pesquisa realizada em julho de 2011 apontava a decisão sobre as uniões estáveis entre pessoas do mesmo sexo como a decisão do Supremo Tribunal Federal mais lembrada pelos entrevistados ${ }^{32}$. Em verdade, os próprios ministros costumam realçar o potencial de reverberação de suas decisões sobre tais assuntos. Em 20 de fevereiro de 2018, por exemplo, durante o julgamento do HC 143641, o Habeas Corpus coletivo sobre a conversão de prisão preventiva em prisão domiciliar de rés grávidas ou mães de crianças de até 12 anos ou de filhos com deficiência, o Ministro Ricardo Lewandowski afirmou, sem modéstia:

Eu tenho a conviç̧ão, a certeza de que as organizações internacionais e as entidades nacionais de proteção dos direitos humanos estão de olhos voltados agora para a Suprema Corte do Brasil; não só essas pessoas jurídicas, mas também todos aqueles que se preocupam com a defesa dos direitos e garantias fundamentais da cidadania (Lewandowski, HC 143641, p. 59).

A notoriedade dessas decisões e seu impacto na crescente visibilidade do Supremo Tribunal Federal e dos seus ministros expressam, no entanto, apenas parte da relevância de tais decisões para os atuais conflitos em torno das fronteiras de nossa experiência democrática. É que através delas, embora não apenas delas certamente, os ministros se têm atribuído intensamente competências para ação. Nós argumentamos, algumas páginas atrás, que minorias e vulneráveis têm constituído condições de possibilidade para práticas e decisões dos ministros do STF. Dá-se,

\footnotetext{
32 De acordo com o Falcão e Oliveira (2013), a pesquisa em questão foi conduzida pelo Centro de Justiça e Sociedade (CJUS) da Escola de Direito da Fundação Getúlio Vargas do Rio de Janeiro, em parceria com o Hello Research, e partiu da indagação sobre como a população brasileira percebe e reage à presença do STF no cenário público nacional. Entre seus achados, a pesquisa produziu os seguintes dados: "A decisão do STF mais citada foi a que reconheceu a união estável para casais do mesmo sexo (união homoafetiva), mencionada por 23\% dos entrevistados; em seguida, aparece a que concedeu liberdade ao italiano Cesare Battisti, citada por $13 \%$ e, em terceiro lugar, a que autorizou as passeatas conhecidas como 'marchas da maconha', mencionada por 7\%" (Falcão e Oliveira, 2013, p. 454).
} 
contudo, que a inexorável vitimização desses sujeitos parece engendrar uma legitimidade maximizada e dotada de urgência para essas ações e decisões, o que o julgamento da ADO 26 e do MI 4733, por exemplo, consegue apontar com relativa facilidade.

Como dissemos, o julgamento dessas duas ações sobre a criminalização da homofobia foi emblemático do que estamos chamando de gramática do sofrimento e de articulação da figura da vítima para o reconhecimento de direitos e a figuração de sujeitos de direitos. Nele, no julgamento, discutia-se a "omissão" dos parlamentares do Congresso Nacional e, desse modo, a possibilidade ou mesmo a necessidade de os ministros enfrentarem-na. A minoria vitimável que precisava ser preservada e o objeto de debates e decisão favoreceram, dessa maneira, a criação de um cenário narrativo de autolegitimação, em que os ministros se moviam contra os outros poderes da república. Segundo Celso de Mello, o Supremo "ao suprir as omissões inconstitucionais dos órgãos estatais" atua para restaurar "a Constituição violada pela inércia dos poderes do Estado" e, com isso, "nada mais faz senão cumprir a sua missão constitucional e demonstrar, com esse gesto, o respeito incondicional que tem pela autoridade da Lei Fundamental da República" (ADO 26 e MI 4733, p. 151). O ministro decano do tribunal, portanto, alega decidir em respeito à Constituição. Luís Roberto Barroso, no entanto, ao decidir contra o que seria uma omissão dos parlamentares, vai além e se põe em defesa da democracia ${ }^{33}$.

Quando o Congresso não atua em situação em que havia um mandamento constitucional para que atuasse, aí eu penso que o papel do Supremo se amplia legitimamente para fazer valer a Constituição [...] Quando estejam em jogo os direitos fundamentais ou as regras do jogo democrático, aí sim se justifica uma postura mais proativa do Supremo, porque esta é a verdadeira missão do Supremo: proteger direitos fundamentais e proteger as regras da democracia (Luís Roberto Barroso, ADO 26 e MI 4733).

Essa tensão entre a atuação dos ministros do Supremo e a experiência democrática tem sido frequentemente lida na chave da "judicialização da política". Tomada de empréstimo da obra inaugural de Tate e Vallinder (1996), a expressão "judicialização da política” costuma remeter à ideia de expansão do Poder Judiciário e de seus agentes no processo decisório das democracias contemporâneas. No entanto, sua rápida e ampla circulação no debate público brasileiro, dos meios de comunicação de massa à bibliografia especializada, gerou uma profusão de sentidos para

\footnotetext{
33 Luis Felipe Miguel e Daniel Bogéa (2020) publicaram recentemente um interessantíssimo artigo em que põem sob escrutínio a ideia de um tribunal judicial como representante argumentativo do povo. $\mathrm{O}$ citado ministro Luís Roberto Barroso, como os autores bem demonstram, defende abertamente tal ideia.
} 
a expressão, por vezes contraditórios e de regra normativos, como notaram Débora Alves Maciel e Andrei Koerner (2002) já há alguns anos.

Os usos analíticos da expressão “judicialização da política” oscilam entre a pretensão de descrever determinado fenômeno e o objetivo de prescrever a melhor conduta para a relação entre agentes do Judiciário, em especial do STF, e a democracia. Assim, esses usos no Brasil ora, por exemplo, demonstram-se entusiastas da participação de agentes do Judiciário na experiência democrática (Barroso, 2018; Progrebinschi, 2013), ora ressaltam a relevância de decisões judiciais para a ampliação de direitos (Avritzer e Marona, 2014), ora expõem críticas contundentes à concentração de poderes no Supremo e em seus ministros, assinalando sua falta de legitimidade democrática (Vieira, 2008; Arguelhes e Ribeiro, 2018) ${ }^{34}$.

Em meio a suas divergências, porém, esses usos da expressão normalmente compartilham algumas noções fundamentais, como as presentes na pressuposição de existência de uma "intervenção" (judicial, dos julgadores, do direito etc.) que borra ou invade "limites" (da divisão dos poderes, das competências, da política etc.) anteriormente demarcados. Assim, aquela "intervenção" pode ser definida como "excessiva", porque invade aqueles limites e carece de legitimidade, ou como decorrente de uma "falta" alheia, que confere legitimidade a quem intervém diante da passividade de outro. É notável, entretanto, que diferentes usos da expressão "judicialização da política" se valham de controvérsias públicas relativas a gênero e sexualidade para significar o que é limítrofe, excessivo ou faltante, objeto de intervenção.

Na literatura sobre o tema, chama atenção o fato de que controvérsias públicas de gênero e sexualidade são insistentemente convocadas para exemplificar ou consubstanciar processos decisórios que parecem tensionar ou expor as fronteiras da democracia ${ }^{35}$. Por sua vez, também chama atenção o fato de que esse tensionamento e essa exposição de fronteiras se deem

34 Não é nossa intenção, neste trabalho, esgotar os diversos empregos da expressão "judicialização da política" na literatura nacional. Destacamos somente a pluralidade, a elasticidade e as contradições em seu uso como conceito, ratificando a crítica desenvolvida por Maciel e Koerner (2002) à costumeira atribuição de um sentido normativo à expressão. Para um melhor acesso às discussões sobre a difícil relação entre o Supremo Tribunal Federal e a democracia brasileira, sugerimos a leitura de trabalhos recentes como os de Avritzer e Marona (2014), Marona e Rocha (2017), Arguelhes e Ribeiro (2018) e Miguel e Bogéa (2020), os quais divergem entre si e oferecem, inclusive em razão de suas diferenças, um interessante "estado da arte" dessas discussões, ainda que esse não consista em seu objeto central.

35 No trabalho de Avritzer e Marona (2014), por exemplo, direitos relativos à diversidade sexual e de gênero aparecem na curta lista exemplificativa de "ampliação" de direitos que os autores apresentam, composta pelos "direitos dos povos indígenas, da ação afirmativa e da união homoafetiva" (Avritzer e Marona, 2014, p. 88). Por sua vez, o trabalho de Oscar Vilhena Vieira (2008) toma a decisão dos ministros do STF junto à ADI 3510, acerca das pesquisas com células-tronco embrionárias, como exemplo do que possibilitaria a "supremocracia" e a apreciação judicial indevida de decisão legislativa anterior legítima. Já Barroso (2018) menciona as "uniões homoafetivas" e o aborto, ao lado da descriminalização de "drogas leves", como exemplos de questões polêmicas que determinados atores políticos preferem que sejam decididas pelo Poder Judiciário, o que conformaria uma das causas da "judicialização da vida" (Barroso, 2018, p. 2177). 
através do recurso a uma linguagem profundamente marcada por convenções morais de gênero e sexualidade, repleta de preocupações com "intervenções", "limites", "excessos" e "faltas". No extremo, considerando o que os diversos usos da expressão "judicialização da política” guardam em comum, não é de estranhar que agentes e setores sociais conservadores também a empreguem acusatoriamente nos conflitos políticos de que participam ${ }^{36}$, opondo-se ao reconhecimento dos direitos sexuais e reprodutivos e daqueles relacionados à diversidade sexual e de gênero.

Parece-nos, desse modo, que a noção de "judicialização da política" não consiste numa chave compreensiva adequada para o tratamento das tensões entre as práticas e decisões dos ministros do Supremo Tribunal Federal, as controvérsias públicas de gênero e sexualidade e nossa experiência democrática. Isto de pronto porque a ideia de "judicialização da política" supõe a existência de duas exterioridades, o direito e a política. Esta suposição remete a processos de Estado de constituição de fronteiras, a esforços de separação que são, como de costume, profundamente tramados em relações de gênero e de sexualidade, como se deu com o esforço da ministra Cármen Lúcia em opor a razão jurídica à emoção popular, o "cidadão democrata" ao povo e à política, como nós já discutimos. Além disso, a ideia de "judicialização da política" acaba também pressupondo a preservação dos agentes judiciais e de suas práticas. Dá-se como se apenas os julgadores que "se excedem" atuassem politicamente, os demais não. Dá-se como se suas práticas cotidianas, seus modos de decidir e arquitetar seus documentos, sentenças e acórdãos não fossem políticos.

Talvez um primeiro passo interessante para a compreensão das tensões entre as práticas e decisões dos ministros do Supremo Tribunal Federal, as controvérsias públicas de gênero e sexualidade e nossa experiência democrática esteja no investimento analítico em uma correlação entre essas tensões, os processos de constituição de Estado e diferentes conflitos judiciais ou por direitos. Provocar essa correlação poderia conduzir-nos reciprocamente a

36 Em entrevista concedida à Folha de S. Paulo em outubro de 2016, a pesquisadora Christina Vital já sublinhava o interesse de grupos evangélicos no Supremo Tribunal Federal e o seu manejo da expressão "judicialização da política": "Desde pelo menos 2006, o Judiciário tem sido o Poder que vinha possibilitando a garantia de direitos de algumas minorias, direitos ameaçados, digamos assim, pelo comportamento legislativo. Os evangélicos falam de uma judicialização da política e eles estavam se organizando para combate-la" (Folha de S. Paulo, 2016). Ver: https://www1.folha.uol.com.br/poder/eleicoes2016/2016/10/1827942-estrategia-evangelica-e-ocupar-o-executivo-para-chegar-ao-judiciario-dizpesquisadora.shtml. 
investigar como gênero e sexualidade operam em conflitos a priori não atinentes a controvérsias públicas de gênero e sexualidade ${ }^{37}$.

Um segundo passo para a discussão acerca dessas tensões poderia dar-se com sua localização em meio ao que Sérgio Carrara $(2015 ; 2016)$ tem chamado de "linguagem dos direitos humanos", que corresponderia a um "novo" regime secular da sexualidade, associado a uma forma própria de regulação moral. De acordo com Carrara, a sexualidade se constitui como objeto de regulação enquanto as reivindicações por direitos sexuais avançam, o que exige de nós a ponderação sobre os preços de nossas próprias conquistas. Essa linguagem de direitos, de certo, tem aberto margem para a emergência de demandas por direitos e reconhecimento em torno de sistemas de justiça e, em especial, de cortes constitucionais. Este fenômeno evidentemente não se restringe ao Brasil e, em várias contextos, antecede-nos. O que ajuda a explicar, ao menos em parte, o que faz com que nossos ministros se voltem frequentemente a cortes europeias, como acontece no também já citado longo voto do ministro Gilmar Mendes junto à ADPF 3510, acerca das pesquisas com células-tronco.

Enfim, um terceiro passo para a compreensão das tensões entre as práticas e decisões dos ministros do Supremo Tribunal Federal, as controvérsias públicas de gênero e sexualidade e nossa experiência democrática talvez também esteja em sua profunda e cortante localização nos conflitos em torno das fronteiras dessa democracia. É notável, por exemplo, a centralidade dessas controvérsias nos conflitos políticos que atravessamos, mais explicitamente desde que se iniciou aquilo que Ronaldo de Almeida (2019) tem chamado de "a crise brasileira", dimensão de um processo internacional de emergência conservadora bem mais amplo, e da qual participam com relevância segmentos religiosos que costumam compreender os ministros do STF como seus adversários políticos. Não à toa, em julho de 2019, durante um culto evangélico na Câmara dos Deputados, o presidente Jair Bolsonaro anunciou que indicará um "ministro terrivelmente evangélico" para o Supremo, ratificando declaração anterior e contrária à decisão dos ministros da corte que levou à criminalização da homofobia e da transfobia. Na ocasião da declaração, Bolsonaro acusou os ministros de estarem "legislando" 38 .

\footnotetext{
37 Em artigo publicado em número anterior desta Direito \& Práxis, Efrem Filho (2018) analisa diferentes formas como relações de gênero e de sexualidade operam na tessitura narrativa do Habeas Corpus de Lula no STF.

38 Para acesso à matéria do G1 sobre as declarações de Jair Bolsonaro, ver: https://g1.globo.com/politica/noticia/2019/07/10/bolsonaro-diz-que-vai-indicar-ministro-terrivelmenteevangelico-para-o-stf.ghtml. Acessos em: 21/04/2020.
} 
Referências Bibliográficas

ABRAMS, Philip. Notes on the difficulty of studying the State (1977). Journal of Historical Sociology, v. 01, n. 01, 1988, pp. 58-90.

AGUIÃo, Sílvia. Fazer-se no "Estado": uma etnografia sobre o processo de constituição dos "LGBT" como sujeitos de direitos no Brasil contemporâneo. Tese (Doutorado em Ciências Sociais), IFCH / Unicamp, 2014.

ALMEIDA, Heloísa Buarque de; MARACHINI, Laís Ambiel. De médico e de monstro: disputas em torno das categorias de violência sexual no caso Abdelmassih. Cadernos Pagu, 50. Campinas: 2017, e175020.

ALMEIDA, Ronaldo de. Bolsonaro presidente: conservadorismo, evangelismo e a crise brasileira. Novos Estudos CEBRAP, v. 38, n. 01. São Paulo: 2019, pp. 185-213.

ARGUELHES, Diego Werneck; RIBEIRO, Leandro Molhano. Ministocracia: o Supremo Tribunal individual e o processo democrático brasileiro. Novos Estudos CEBRAP, v. 37, n. 01. São Paulo: 2018, pp. 13-32.

AVRITZER, Leonardo; MARONA, Marjorie Corrêa. Judicialização da política no Brasil: ver além do constitucionalismo liberal para ver melhor. Revista Brasileira de Ciência Política, n. 15. Brasília: 2014, pp. 69-94.

BARROSO, Luís Roberto. "Here, There, and Everywhere": Human Dignity in Contemporary Law and in the Transnational Discourse. Boston College International and Comparative Law Review, Vol. 35, No. 2, 2012.

BARROSO, Luís Roberto. A Dignidade da Pessoa Humana no Direito Constitucional Contemporâneo - A Construção de um Conceito Jurídico à Luz da Jurisprudência Mundial. Belo Horizonte: Fórum, 2013.

BARROSO, Luís Roberto. Contramajoritário, representativo e iluminista: os papeis dos tribunais constitucionais nas democracias contemporâneas. Direito \& Práxis, v. 09, n. 04. Rio de Janeiro: 2018, pp. 2171-2228.

BELLAMY, Richard; CASTIGLIONE, Dario. Constitutionalism and Democracy - Political Theory and the American Constitution. British Journal of Political Science, 27, 1997.

BLACKSTONE, William. Commentaries on the Law of England. Oxford: Clarendon Press, 1765-9.

BLANCHETTE, Thadeus Gregory; SILVA, Ana Paula da. O mito de Maria, uma traficada exemplar: confrontando leituras mitológicas do tráfico com as experiências de migrantes brasileiros, trabalhadores do sexo. Revista Interdisciplinar de Mobilidade Humana, n. 37. Brasília: 2011, pp. 79 -105 .

CARRARA, Sérgio. A antropologia e o processo de cidadanização da homossexualidade no Brasil. Cadernos Pagu, v. 47. Campinas: 2016. 
CARRARA, Sérgio. Moralidades, racionalidades e políticas sexuais no Brasil contemporâneo. Mana, v. 21 , n. 02 . Rio de Janeiro: 2015 , pp. $323-345$.

CARRARA, Sérgio; FRANÇA, Isadora Lins; SIMÕES, Júlio Assis. Conhecimento e práticas científicas na esfera pública: antropologia, gênero e sexualidade. Revista de Antropologia, v. 61, n. 01. São Paulo: 2018, pp. 71-82.

CARVALHO, Neuza C. O estranhamento estrangeiro de Caetano Veloso. Revista Miscelânea, UNESP - Assis, v. 1, n.1, 1993, p. 69-86.

CASTRO, Eduardo Viveiros de. No Brasil todo mundo é índio, exceto quem não é. In: AZTUTMAN, Renato (org.). Encontros. Coleção Encontros: a arte da conversa. Rio de Janeiro: Beco do Azougue, 2008.

CIUFFOLETTI, Sofia. Dal Fenomeno del Judicial Borrowing al Dialogo Transnazionale fra Corti. I Nuovi Orizzonti del Dibattito Dottrinale. Tese (Doutorado em Direito), Università degli Studi Pisa, 2011.

COACCI, Thiago. A queima dos laudos: controvérsias e reconfigurações dos saberes e direitos trans na ADI 4275. Direito \& Práxis, v. 11, n. 02. Rio de Janeiro: 2020, pp. 1188-1210.

COACCl, Thiago. Do homossexualismo à homoafetividade: discursos judiciais brasileiros sobre homossexualidades, 1989-2012. Sexualidad, Salud y Sociedad - Revista Latinoamericana, n. 21. Rio de Janeiro: 2015 , pp. $53-84$.

COITINHO FILHO, Ricardo Andrade; RINALDI, Alessandra de Andrade. O Supremo Tribunal Federal e a "união homoafetiva": onde os direitos e as moralidades se cruzam. Civitas, v. 18, n. 01. Porto Alegre: 2018, pp. 26-42.

COKE, Edward. The Second Part of the Institutes of England Containing the Exposititon of Many Ancient and Other Statutes. London: Crooke, 1642.

CORRÊA, Mariza. Morte em família: representações jurídicas de papéis sexuais. Rio de Janeiro: Edições Graal, 1983.

CORRÊA, Sonia. A "política de gênero": um comentário genealógico. Cadernos Pagu, v. 53. Campinas: 2018, e185301.

DEBERT, Guita Grin; GREGORI, Maria Filomena. Violência e gênero: novas propostas, velhos dilemas. Revista Brasileira de Ciências Sociais, v. 23, n. 66. São Paulo: 2008, pp. 165 $-211$.

DICEY, Albert Venn. Introduction to the Study of the law of the Constitution. Indianapolis: Liberty Fund, 1982.

DUPRÉ, Catherine. Unlocking human dignity: towards a theory for the 21st century. European Human Rights Law Review, vol. 2, 2009, pp. 190-205. 
EFREM FILHO, Roberto. "Um paraíso de homicidas, estupradores, corruptos": sexualidade e gênero no julgamento do Habeas Corpus de Lula no STF. Direito \& Práxis, v. 09, n. 03. Rio de Janeiro: 2018, pp. 1871-1896.

EFREM FILHO, Roberto Os meninos de Rosa: sobre vítimas e algozes, crime e violência. Cadernos Pagu, n. 51. Campinas: 2017a, e175106.

EFREM FILHO, Roberto. A reivindicação da violência: gênero, sexualidade e a constituição da vítima. Cadernos Pagu, n. 50. Campinas: 2017b, e175007.

EFREM FILHO, Roberto. Os ciúmes do Direito: o desejo pelas uniões homoafetivas e a repulsa a Amor Divino e Paixão Luz. Sexualidad, Salud y Sociedad - Revista Latinoamericana, n. 16. Rio de Janeiro: 2014, pp. $10-30$.

FACCHINI, Regina. Entre compassos e descompassos: um olhar sobre o "campo" e a "arena" do movimento LGBT brasileiro. Bagoas, n. 04. Natal: 2009, pp. 131 - 158.

FACCHINI, Regina; FERREIRA, Carolina Branco de Castro. Feminismos e violência de gênero no Brasil: apontamentos para o debate. Ciência e Cultura, v. 68, n. 03. Campinas: 2016, 04 - 05.

FACCHINI, Regina; SÍVORI, Horacio. Conservadorismo, direitos, moralidades e violência: situando um conjunto de reflexões a partir da Antropologia. Cadernos Pagu, n. 50. Campinas: 2017, e175000.

FALCÃO, Joaquim; OLIVEIRA, Fabiana Luci de. O STF e a agenda pública nacional: de outro desconhecido a supremo protagonista? Lua Nova, n. 88. São Paulo: 2013, pp. 429 - 469.

FAUSTO-STERLING, Anne. Dualismos em duelo. Cadernos Pagu, n. 17/18. Campinas: 2001/02, pp. $09-79$.

FEITOSA, Cleyton. Políticas públicas LGBT no Brasil: um estudo sobre o Centro Estadual de Combate à Homofobia de Pernambuco. Sexualidad, Salud y Sociedad - Revista Latinoamericana, n. 32. Rio de Janeiro: 2019, pp. 90-118.

FERREIRA, Letícia Carvalho de Mesquita. "Apenas preencher papel": reflexões sobre registros policiais de desaparecimento de pessoa e outros documentos. Mana, v. 19, n. 01. Rio de Janeiro, 2013, pp. $39-68$.

FREIRE, Lucas. A máquina da cidadania: uma etnografia sobre a requalificação civil de pessoas transexuais. Dissertação (Mestrado em Antropologia Social), Museu Nacional / UFRJ, 2015.

GREGORI, Maria Filomena. Contextos de formação: a importância de Mariza Corrêa para uma geração. Cadernos Pagu, n. 54. Campinas: 2018, e185404.

GREGORI, Maria Filomena. Cenas e queixas: um estudo sobre mulheres, relações violentas e a prática feminista. Rio de Janeiro: Paz e Terra; São Paulo: ANPOCS, 1993. 
GRUNVALD, Vitor. Lâmpadas, corpos e cidades: reflexões acadêmico-ativistas sobre arte, dissidência e a ocupação do espaço público. Horizontes Antropológicos, n. 55. Porto Alegre: 2019, pp. $263-290$.

KELSEN, Hans. Jurisdição constitucional. São Paulo: Martins Fontes, 2003.

HENNETTE-VAUCHEZ, Stéphanie. A Human Dignitas? Remnants of the ancient legal concept in contemporary dignity jurisprudence. International Journal of Constitutional Law, vol. 9, n. 1, 2011, pp. 32-57.

JEGANATHAN, Pradeep. Checkpoint: anthropology, identity, and the state. In: DAS, Veena; POOLE, Deborah (eds.). Anthropology in the margins of the state. Santa Fe: School of American Research Press, 2004, pp.67-80.

LACERDA, Paula Mendes. O sofrer, o narrar e o agir: dimensões da mobilização social de familiares de vítimas. Horizontes Antropológicos, v. 20. Porto Alegre: 2014, pp. 45 - 76.

LAGO, Natália Bouças do. Jornadas de visita e luta: tensões, relações e movimentos de familiares nos arredores da prisão. Tese (Doutorado em Antropologia Social), FFLCH / USP, 2019.

LEITE, Vanessa. "Em defesa das crianças e da família": refletindo sobre discursos acionados por atores religiosos "conservadores" em controvérsias públicas envolvendo gênero e sexualidade. Sexualidad, Salud y Sociedad: revista latino-americana, n. 32. Rio de Janeiro: 2019, pp. $119-142$.

LOWENKRON, Laura. Consentimento e vulnerabilidade: alguns cruzamentos entre o abuso sexual infantil e o tráfico de pessoas para fim de exploração sexual. Cadernos Pagu, n. 45 . Campinas: 2015 , pp. $225-258$.

LOWENKRON, Laura. O monstro contemporâneo: a construção social da pedofilia em múltiplos planos. Tese (Doutorado em Antropologia Social), Museu Nacional / UFRJ, 2012.

LUGONES, María Gabriela. ¿Matonato? Gestiones maternales de protección estatal. Cadernos Pagu, n. 51. Campinas: 2017, e175102.

MACHADO, Bernardo Fonseca. Moral do controle: sobre inquietações e propostas para pensar "ideologia de gênero" e o Escola Sem Partido. Cadernos de Campo, v. 28, n. 02. São Paulo: 2019, pp. $32-38$.

MACHADO, Lia Zanotta. Feminismos em movimento. São Paulo: Editora Francis, 2010.

MACHADO, Maria das Dores Campos. O discurso cristão sobre "ideologia de gênero". Revista Estudos Feministas, v. 16, n. 02. Florianópolis: 2018, e47463.

MACIEL, Débora; KOERNER, Andrei. Sentidos da judicialização da política: duas análises. Lua Nova, n. 57. São Paulo: 2002, pp. $113-133$. 
MADSEN, Annette. Count Lucanor by Don Juan Manuel as Inspiration for Hans Christian Andersen and Other European Writers. In: Johan de Mylius, Aage Jørgensen and Viggo Hjørnager Pedersen (ed.). Hans Christian Andersen. A Poet in Time. Anais da II Conferência Internacional Hans Christian Andersen. Odense: The Hans Christian Andersen Center, Odense University, Odense University Press, 1999.

MACKINNON, Catherine. A toward a feminist theory of the state. Cambridge, Massachusetts, London: Harvard University Press, 1989.

MARONA, Marjorie Corrêa; ROCHA, Marta Mendes da. Democratizar a jurisdição constitucional? O caso das audiências públicas no Supremo Tribunal Federal. Revista de Sociologia e Política, v. 25, n. 62. Curitiba: 2017, pp. $131-156$.

MELLO, Breno Marques de. Na selva de pedras: as performances de gênero e sexualidade nos conflitos entre prostituição, crime e Estado. Dissertação (Mestrado em Direito), CCJ / UFPB, 2019.

MELLO, Marília Montenegro Pessoa de; VALENÇA, Manuela Abath. "Pancada de amor não dói": a audiência de custódia e a visibilidade invertida da vítima nos casos de violência doméstica. Direito \& Práxis, v. 11, n. 02. Rio de Janeiro: 2020, pp. 1238-1274.

MIGUEL, Luis Felipe; BOGÉA, Daniel. O juiz constitucional me representa? O Supremo Tribunal Federal e a representação argumentativa. Revista Brasileira de Ciências Sociais, v. 35, n. 104. São Paulo: 2020, e3510402.

MILLNS, Susan. Respect for Human Dignity: an Anglo-French comparison. Tese (Doutorado em Filosofia), University of Ken at Canterbury, Canterbury, 2004.

MITCHELL, Timothy. Siciety, economy and de State effect. In.: STEINMETZ, G. (ed.). State/Culture: state formation after the cultural turn. New York: Cornell University Press, 1999, pp. $76-97$.

MOUTINHO, Laura. Diferenças e desigualdades negociadas: raça, sexualidade e gênero em produções acadêmicas recentes. Cadernos Pagu, n. 42. Campinas: 2014, pp. $201-$ 248.

NADAl, Larissa. Descrever crimes, decifrar convenções narrativas: uma etnografia entre documentos oficiais da Delegacia de Defesa da Mulher de Campinas em casos de estupro e atentado violento ao pudor. Dissertação (Mestrado em Antropologia Social), IFCH / Unicamp, 2012.

PADOVANI, Natália Corazza. Tráfico nas portarias das prisões ou dispositivos de segurança e gênero nos processos de produção das "classes perigosas". Cadernos Pagu, n. 51. Campinas: 2017, e175103.

PASCHOAL, Júlio Emílio Cavalcanti. Sujeito a conselho: uma etnografia sobre atuação do Conselho Estadual dos Direitos da População LGBT do Rio de Janeiro. Dissertação (Mestrado em Direito), Faculdade Nacional de Direito / UFRJ, 2020. 
PASINATO, Wânia. "Feminicídios" e as mortes de mulheres no Brasil. Cadernos Pagu, n. 37. Campinas: 2011, pp. $219-246$.

PISCITELLI, Adriana; LOWENKRON, Laura. Categorias em movimento: a gestão de vítimas do tráfico de pessoas na Espanha e no Brasil. Ciência e Cultura, v. 67, n. 02. São Paulo: 2015, pp. $35-39$.

POGREBINSCHI, Thamy. Judicialização ou representação? Política, direito e democracia no Brasil. Rio de Janeiro: Elsevier, 2013.

PONTES, Heloisa; GREGORI, Maria Filomena. Mariza Corrêa: laços, memória e escritos. Cadernos Pagu, n. 54. Campinas: 2018, e185400.

PROPP, Vladimir. Morphology of the folktale (1928). University of Texas Press, 1968.

RINALDI, Alessandra. Da homossexualidade à "homoafetividade": trajetórias adotivas no Rio de Janeiro. Interseções, v. 16, n. 02. Rio de Janeiro: 2014, pp. 283 - 306.

ROCHA, Gilmar. Etnopoética do olhar. Sociedade e Cultura, n. 04, n. 01. Goiânia: 2001, pp. $145-163$.

RONDON, Gabriela. O gênero da dignidade: humanismo secular e proibição de tortura para a questão do aborto na ADPF 54. Direito \& Práxis, v. 11, n. 02. Rio de Janeiro: 2020, pp. 1137-1165.

RUIBAL, Alba M. A controvérsia constitucional do aborto no Brasil: inovação na interação entre movimento social e Supremo Tribunal Federal. Direito \& Práxis, v. 11, n. 02. Rio de Janeiro: 2020, pp. 1166-1187.

SANTORO, Emilio. Rule of law e 'liberdade dos ingleses': a interpretação de Albert Venn Dicey. In: COSTA, Pietro; ZOLO, Danilo (orgs). O Estado de Direito: história, teoria, crítica. São Paulo: Martins Fontes, 2006.

SARTI, Cynthia. A vítima como figura contemporânea. Cadernos $C R H, 24$ (61). Salvador: 2011, pp. $51-61$.

SCOTT, Joan Wallach. Gênero: uma categoria útil de análise histórica. Revista Educação \& Realidade. Porto Alegre, vol. 20, no 2,jul./dez. 1995, pp. 71-99.

SLAUGHTER, Anne-Marie. International Law in a World of Liberal States. European Journal of International Law, Volume 6, Issue 3, 1995, Pages 503-538.

SLAUGHTER, Anne-Marie. A New World Order: Government Networks and the Disaggregated State. Princeton: Princeton University Press. 2004.

RODRIGUEZ, José Rodrigo. Como decidem as cortes? Para uma crítica do direito (brasileiro). Rio de Janeiro: Ed. FGV, 2013.

ROSEN, Michael. Dignity: its history and meaning. Cambridge, Massachusetts, London: Harvard University Press, 2012. 
SANTOS, Carlos Victor Nascimento dos. O Supremo e as lições de Lewandowski. Anais do 41 Encontro Anual da ANPOCS, 2017.

TATE, C. Neal; VALLINDER, Torbjorn. The global expansion of Judicial Power. New York University Press, 1995.

VEIGA, Cilmara. O caso do maníaco matador de velhinhas: entre trâmites processuais e diferentes formas de narrar que enredam um crime em série. Dissertação (Mestrado em Antropologia Social), IFCH / Unicamp, 2018.

VELOSO, Caetano. Letra só / Sobre as Letras (2 vol.). São Paulo: Companhia das Letras, 2003.

VIANNA, Adriana; FARIAS, Juliana. A guerra das mães: dor e política em situações de violência institucional. Cadernos Pagu, n. 37. Campinas: 2011, pp. 79-116.

VIANNA, Adriana; LOWENKRON, Laura. O duplo fazer do gênero e do Estado: interconexões, materialidades e linguagens. Cadernos Pagu, 51. Campinas: 2017, e175101.

VIEIRA, Adriana Dias. Os sentidos da noção de dignidade humana em disputa: consonâncias e dissonâncias discursivas no campo jurídico. Tese (Doutorado em Direito), UNIFI, 2014.

VIEIRA, Oscar Vilhena. Supremocracia. Revista Direito GV, v. 04, n. 02. Rio de Janeiro: 2008, pp. 441 -463 .

VOJVODIC, Adriana de Moraes; MACHADO, Ana Mara França; CARDOSO, Evorah Lusci Costa. Escrevendo um romance, primeiro capítulo: precedentes e processo decisório no STF. Rev. direito GV, São Paulo, v. 5, n. 1, 2009, p. 21-44.

WALDRON, Jeremy. Dignity, rank and rights. Oxford University Press, Oxford, 2012.

WISNIK, José Miguel. Maquinação do mundo: Drummond e a mineração. São Paulo: Companhia das Letras, 2018.

WHITMAN, James. On Nazi 'Honor' and the New European 'Dignity', in C. JOERGES e N. SINGH GHALEIGH (org.). Darker Legacies of Law in Europe: The Shadow of National Socialism and Fascism over Europe and its Legal Traditions. Oxford: Hart Publishing, 2003.

WHITMAN, James. The Two Western Cultures of Privacy: Dignity versus Liberty, Yale Law Journal, 113, 2004.

ZAMBONI, Marcela; OLIVEIRA, Helma J. S.; NASCIMENTO, Emylli Tavares do. Intersecções de gênero, sexualidade e classe em tribunais do júri: valores morais em disputa. Revista Brasileira de Sociologia, v. 07, n. 15. Belo Horizonte: 2019, pp. 190-214. 


\section{Sites Consultados}

CNJ. Casamento homoafetivo: norma completa quatro anos. CNJ, mai. 2017. Disponível em: https://www.cnj.jus.br/lei-sobre-casamento-entre-pessoas-do-mesmo-sexo-completa4-anos/. Acesso em 28/04/2020.

FOLHA DE S. PAULO. Estratégia evangélica é ocupar o Executivo para chegar ao Judiciário, diz pesquisadora. Folha de S. Paulo, out. 2016. Disponível em: https://www1.folha.uol.com.br/poder/eleicoes-2016/2016/10/1827942-estrategia-evangelicae-ocupar-o-executivo-para-chegar-ao-judiciario-diz-pesquisadora.shtml. Acesso em: 21/04/2020.

G1. Bolsonaro diz que vai indicar ministro 'terrivelmente evangélico' para o STF. G1, jul. de 2019. Disponível em: https://g1.globo.com/politica/noticia/2019/07/10/bolsonaro-diz-que-vaiindicar-ministro-terrivelmente-evangelico-para-o-stf.ghtml. Acesso em: 21/04/2020

G1. Jovens que agrediram gay na Paulista com lâmpada terão que pagar multa de $\mathrm{R} \$ 25,7$ mil. G1, out. de 2018. Disponível em: https://g1.globo.com/sp/sao-paulo/noticia/2018/10/18/jovensque-agrediram-gay-na-paulista-com-lampada-terao-que-pagar-multa-de-r-257-mil.ghtml. Acesso em: 28/04/2020.

STF. Lei municipal que proíbe ensino sobre questões de gênero é inconstitucional. STF, abr. de 2020.

http://www.stf.jus.br/portal/cms/verNoticiaDetalhe.asp?idConteudo=442331. Acesso em: 29 de abril de 2020.

\section{Sobre os autores \\ Adriana Dias Vieira \\ Professora da Faculdade de Direito e do Programa de Pós-Graduação em Direitos, Instituições e Negócios da Universidade Federal Fluminense e professora colaboradora no Programa de Pós-Graduação em Ciências Jurídicas da Universidade Federal da Paraíba. Doutora em Direito junto à Università degli Studi di Firenze e em Sociologia junto à Universidade Federal da Paraíba, onde também concluiu graduação e mestrado em Direito. E-mail: a.diasvieira@gmail.com}

\section{Roberto Efrem Filho}

Professor do Departamento de Ciências Jurídicas da Universidade Federal da Paraíba e do Programa de Pós-Graduação em Antropologia da Universidade Federal de Pernambuco. Doutor em Ciências Sociais junto à Universidade Estadual de Campinas e mestre e graduado em Direito pela Universidade Federal de Pernambuco. E-mail: robertoefremfilho@gmail.com

Os autores contribuíram igualmente para a redação do artigo. 